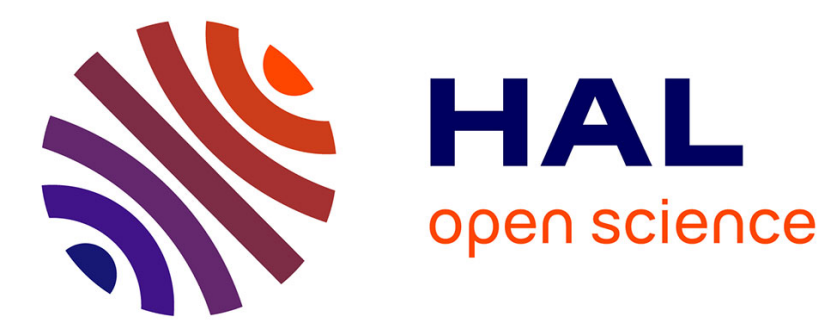

\title{
Continuity and discontinuity during hominization
}

Anne Dambricourt-Malassé

\section{To cite this version:}

Anne Dambricourt-Malassé. Continuity and discontinuity during hominization. Quaternary International, 1993, 19, pp.85-98. 10.406182/93 . halshs-00425054

\section{HAL Id: halshs-00425054 https://shs.hal.science/halshs-00425054}

Submitted on 19 Oct 2009

HAL is a multi-disciplinary open access archive for the deposit and dissemination of scientific research documents, whether they are published or not. The documents may come from teaching and research institutions in France or abroad, or from public or private research centers.
L'archive ouverte pluridisciplinaire HAL, est destinée au dépôt et à la diffusion de documents scientifiques de niveau recherche, publiés ou non, émanant des établissements d'enseignement et de recherche français ou étrangers, des laboratoires publics ou privés. 


\title{
CONTINUITY AND DISCONTINUITY DURING HOMINIZATION
}

\author{
Anne Dambricourt Malassé \\ Institut de Paléontologie humaine, URA 184 CNRS, 1 rue Panhard, F-75013 Paris, France
}

\begin{abstract}
Recent observations on an ontogenetic craniofacial phenomenon have led to new concepts of facial morphogenesis and to recognition of a process called craniofacial contraction. This begins at embryogenesis, in association with the growth of the brain. The degree of process called cration into four ontogenic levels: prosimians, monkeys, apes and Homo sapiens ('Sapiens'). The phenomenon is modeled and quantified using an architectural analysis, the prosimians, monkeys, apes and Homo sapiens ('Sapiens'). The phenomenon is modeled and quantified using an arche double pantograph. The hypothesis is that hominization represents a continous phenomenon from fossil apes to Sapiens, i.e. an increase in the embryonic contraction, but with discontinous effects, i.e. ontogenic organization plans. The fossil hominid record verifies the the embryonic contraction, but with discontinous efest of craniofacial contraction, with three ontogenic thresholds: Australopithecus, hypothesis. Hominization appears as a continuous process of craniofacial contraction, with three ontoge contraction of Homo erectus, in Homo and Sapiens. Neanderthal man is not Sapiens. He results from a decrease in the embryonic contraction of Homo ene association with an impoverishment of the meningeal vascularization. Sapiens does not emerge before skulls such as Qafzeh. The increase no ontogenic reality.
\end{abstract}

\section{DEFINITION OF SAPIENS}

The Dmanassi mandible discovered in 1991 in Georgia represents the oldest record of human presence in Europe (1.5 Ma, Bosinsky, pers. commun., 1993). The question is whether it is Homo erectus or an archaic Homo sapiens, since European fossils are in general not taxonomically well defined. For example, there is no consensus on the specific allocation of specimens from Mauer, Steinheim, Arago and Swanscombe. Neanderthal man appears at around 120,000 BP (Condemi, 1991) and is commonly identified by paleoanthropologists as $H$. sapiens and therefore as conspecific with modern man. What, then, are the diagnostic characters of $H$. sapiens? In order to answer this question, I believe it necessary to define the ontogenic organizational plan of Homo sapiens. I shall call this organizational plan 'Sapiens' and raise the question whether it is present in late $H$. erectus, i.e. those known as archaic $H$. sapiens. Can late $H$. erectus with large brains be identified as Sapiens in their ontogenic development?

To study these issues I have introduced the notion of fundamental ontogenesis (Dambricourt Malassé, 1988), which represents the basis for a definition of an objective biological unity. By definition, a fundamental ontogenesis includes all the individuals sharing the same fundamental ontogenic plan, namely a plan which is recognizable at the adult stage, for instance by a clearly defined organization of the skull.

The concept of heterochrony has long been used in paleontology (Devaux, 1921; Bolk, 1926; Dechambre, 1928; Tobias, 1967; Gould, 1977; Heim, 1982; Saban, 1984). Today it reappears frequently. However, studies which take into consideration ontogenesis for the understanding of hominization extrapolate their observations from the extant apes and not from fossils. Studies on the growth tempo of australopithecines are still rare (Bromage, 1985, 1987, 1989) and they still compare the fossil hominids with the ontogenic pathways of the living apes. This reasoning assumes implicitly that dryopithecine (fossil ape sensu lato) ontogeneses are identical to those of living apes. However, there is no a priori reason why this should be so.

My focus is, on the other hand, the reconstruction of fossil ontogeneses, or paleontogeneses (Dambricourt Malassé, 1987), which can be considered as the ancestral basis of $H$. sapiens. The juxtaposition of these paleontogeneses and the living ontogeneses allows us to deduce in what way the living species provide information for an evolutionary interpretation.

In order to conduct this study, it is necessary to examine the skeletal element most commonly found in the fossil record. In the case of humans this is the mandibular corpus. One might object that the mandible is not appropriate for this kind of reconstruction. However, I would like to point out the following. Embryonic development proceeds in the cephalocaudal direction (head-pelvis). In other words, there is a chronological and spatial time lag in embryonic organization. The cephalic pole is the first to show differentiation, followed by the shoulders and the anterior members and then the posterior members and the pelvis (Schultz, 1926; Langman, 1984). This time lag leads us to new hypotheses as far as the ontogenic process is concerned, with the notion of gradient fields and homeobox genes. This means that any rearrangment of the postcranial skeleton can occur without prior cephalic reorganization, which includes the development of the mandible. The question is first to ascertain whether the cephalic reorganization is observed in the mandible. According to the general principle of cephalocaudal organization, one should then expect that cephalic reorganization is followed by a subsequent reorganization of the postcranial skeleton. Therefore, theoretically, a reorganization of the skull starting with embryogenesis ought to be contemporaneous with the restructuring of the pelvis. I have proposed to explain the important anatomical changes of the australopithecine cephalocaudal axis as the result of this phenomenon (Dambricourt Malassé, 1988).

In order to determine whether the mandible is a good 
pointer to cephalic ontogenesis, it is logical to start the study with the embryonic phase, taking into account the cephalic network, i.e. the cartilaginous, bony, vascular and neural tissues. Thus, it is necessary to compare the human ontogenic pathway with that of other modern primates, or at least with the apes.

The method I advocate consists of developing an ontogenic diagnostic of adult bones, in this case the mandible, starting with the living species of primates. In its biometric and anatomic characteristics, it will show an ontogenetic correlation with other tissues acquired since embryogenesis. This will give us additional information on the ontogenic causes which differentiate groups of species. It also provides affiliations and a sense of possible evolutionary causalities. I will then determine whether the diagnostic is applicable to adult or young mandibles, in order to ascertain whether it is possible to retrace their ontogenesis, starting with embryogenesis. The conclusions obtained from an isolated mandible are then compared with the observations made on the skulls.

The results show that skulls and mandibles follow the same ontogenic pattern. Their ontogenic regrouping is in accord with classical anatomical classifications. The only questions which require reconsideration are the position of of Neandertals and the concept of archaic H. sapiens.

\section{THE ONTOGENIC APPROACH TO CRANIOFACIAL ARCHITECTURE}

\section{The Ontogenetic Phenomenon of 'Craniofacial Contraction'}

A recently discovered craniofacial phenomenon completely overturns our understanding of ontogenic modalities. It has been experimentally tested in dentofacial orthopedics (Deshayes, 1986) and its basic principles have been laid out in a series of publications (Deshayes, 1988, 1991, in press, a, b; Deshayes and Dambricourt Malassé, 1990; Deshayes et al., 1992; Dambricourt Malassé, 1992a; Dambricourt Malassé and Deshayes, 1992; Choukroun, in press; Courtot, in press).

The broad outline of this phenomenon is as follows: the morphogenesis of the basal part of skull is governed by dynamic strains and these basicranial strains determine the three-dimensional organization of the face and the location and shape of the sutures. The craniofacial system is a constant readjustment of the position of the membranous tissues (bone and cartilage) in all three dimensions (Deshayes, 1986; Deshayes and Dambricourt Malassé, 1990; Dambricourt Malassé, 1992b). This complex analysis is described in Deshayes (1986). I will just present some examples. We make a distinction between two ontogenic trends in craniofacial diseases: skulls in extension and skulls in flexion (Fig. 1). Many facial diseases are the result of dynamical disequilibria within the basicranium, in association with the phenomenon of occipital flexion. This last phenomenon, i.e. occipital flexion, has been known for a long time (Bolk, 1909; Anthony, 1952; Ashton and Zuckerman, 1956; Delattre and Fenart, 1960). Its implications for the shape of the squama of the vault and for the organization of the cranial sutures are well described in the work of Delattre and Fenart (1960) (Fig. 2B). What is new is the biodynamic ontogenetic relationship between occipital flexion and facial morphogenesis. The first ontogenic links appear in the work of Gudin (1952), who developed an architectural and dynamical analysis called "pantographe de Gudin" (Godard et al., 1973) (Fig.2A). In 1978, Delaire defined a craniofacial analysis which was static (Delaire et al., 1981). Nowadays, this analysis has been transformed and can be used with great efficiency through the dynamization of Deshayes (Fig. 3).

In my observations (Fig. 4) I have rediscovered the morphogenic principles of the pantograph (1) during embryogenesis and (2) during hominization (Dambricourt Malassé, 1987).

\section{Causes of the Craniofacial Phenomenon}

The most important causal factors occur during embryogenesis (Figs 5 and 6). The morphogenesis of the skull begins in the cartilaginous tissue under the neural tube. The cartilaginous embryonic cranium has two parts (Kernan, 1916), the pars chordalis and the pars praechordalis. At first, the major part of the embryonic skull is represented by the pars chordalis, (the part defined by the presence of the chord, rhombencephalon, Fig. 5A) which corresponds to the planum basale (Fig. 5E). This will undergo a deformation which has two chronological origins: between embryonic stages 17 and 20 the posterior part of the planum straightens up, and then from stage $20 \mathrm{a} 45^{\circ}$ rotation of the planum occurs. This latter rotation represents the occipital flexion. The otic capsules (Figs 5C,D,E) are linked to the cartilaginous arch of the embryonic mandible and are already fused together with the planum before the occurrence of the flexion. Therefore, they rotate with the occipital flexion and create a morphodynamic link with the mandibular arch. As far as I know the causes of this cartilaginous occipital flexion have not previously been described. Thus, I have tried to investigate the contemporaneous neural phenomena in order to ascertain whether there exist correlations within the cephalic system.

The morphodynamic movement of the neural plate into a tube is described by Jacobson (1978). These neural dynamics create a rotation and elongation of the neural tube just above the apex of the chord (Fig. 6), which represents the axis of the rotation.

The cartesian axes allow us to observe the neural growth in space. We can see the progressive elongation of the prechordal part during the rotation. When it exceeds $90^{\circ}$ (Fig. 6.6), the occipital kyphosis begins, with changes in the mandibular morphogenesis. The rotation of the otic capsules appears to increase the growth of the anterior part of the mandibular arch in the vertical plane rather than in the horizontal one, as was described in Bolk (1924) (Fig. 7). When we observe the morphogenesis of the anterior part of the mandible, we see a triangular gap developing. This gap will be preserved until the adult stage and corresponds to the ossified trigonum mentale (Fig. 7C,D). At the same time, two small depressions emerge on both sides of the symphyseal axis, the fossae mentales. This embryonic craniofacial morphogenesis is in accord with the 'movement' of craniofacial contraction and can be modelled by a pantograph (Fig. 5C). The triangular gap reflects the amplitude of the embryonic neural rotation 

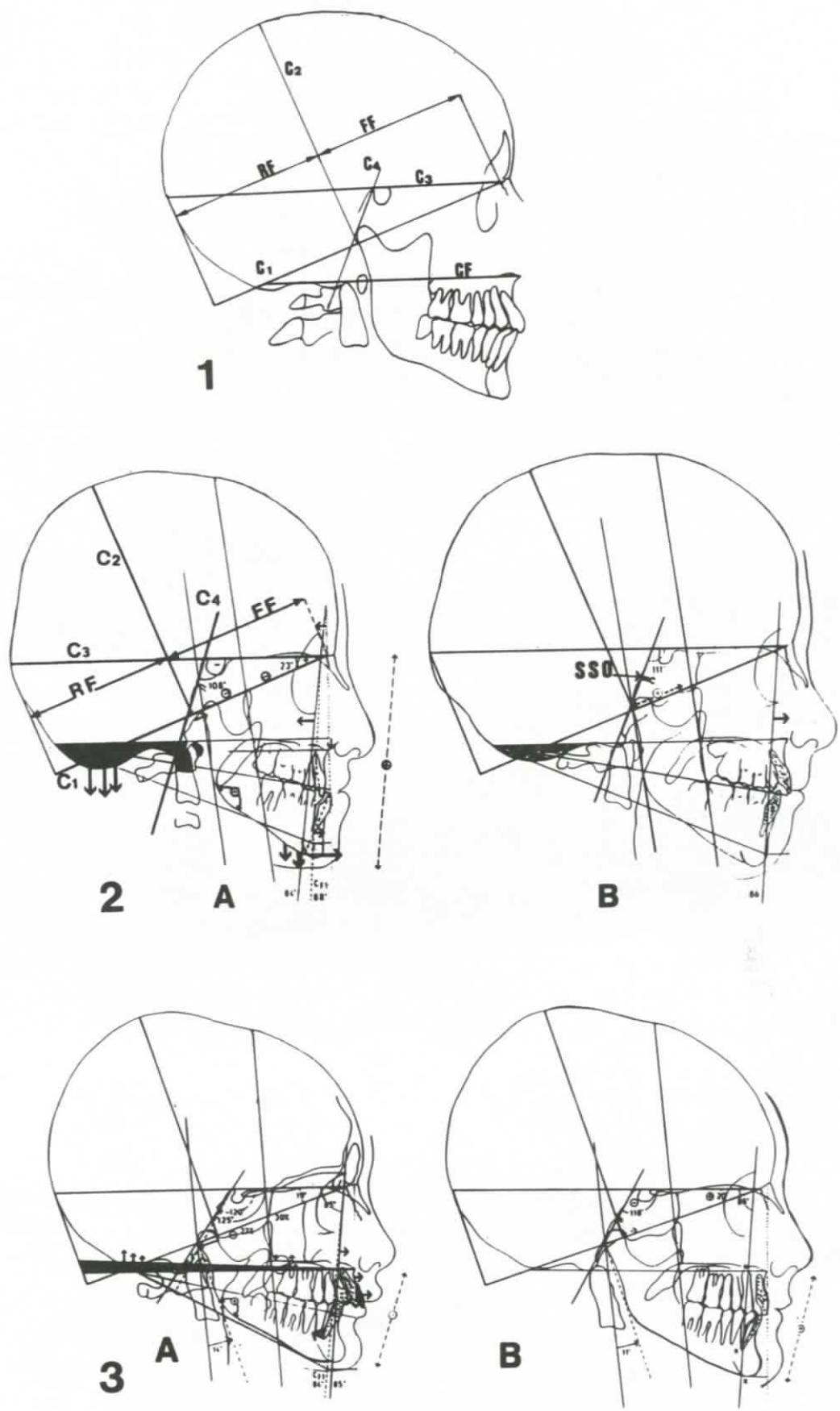

FIG. 1. Craniofacial architectural analysis (Deshayes, 1986). (1) 'Ideal equilibrium', as defined in Delaire (1978). This equilibrium seems to FIG. 1. Craniofacial architectural analysis (Deshayes, 1986). (1) 'Ideal equilibrium', as defined in Delaire (1978) be limited to the european architecture (Deshayes, in press); (2) Rearrangement of a great juvenile flexion after orthopedic appliances. (3) Rearrangement of a juvenile dysmorphosis; (2B) new equilibrium. Notice the change of the vault and of the occipital squama (in black); (3) Rearrangement of a juve

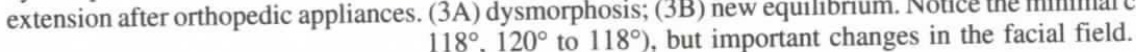

and the fossae mentales are the result of independent morphogenic pathways between the alveolar and the basal sections of the mandible. The spatial organization of the mandibular bony trabecules is also in accord with a morphodynamical field corresponding to a form of contraction.

Occipital flexion evolves during fetal growth (Müller and O'Rahilly, 1980a), as indicated by the closure of the sphenoidal angle from $133^{\circ}$ (embryo $20 \mathrm{~mm}$ ) to $106^{\circ}$ (fetus $93 \mathrm{~mm}$ ). In fact, the craniofacial contraction is maximal during the embryonic period. The mandible then maintains the fundamental organization of the bony trabecules and grows in the transversal plane (Fig. 8A). The space between the two hemimandibles increases quickly from the third to the fourth month. On the basis of fossil material I have identified an angle that quantifies this divergence (Fig. 9D). I call it the "basal mandibular angle". It changes from $60^{\circ}$ in the third month of intra-uterine development to $90^{\circ}$ at birth.

I have added a second pantograph, perpendicular to the first one, which shows the relationship between sagittal occipital flexion and the morphogenesis of the mandibular alveolar section (Fig. 9A,B,C). Through the medium of the temporo-mandibular joints (TMJ), the alveolar unit 

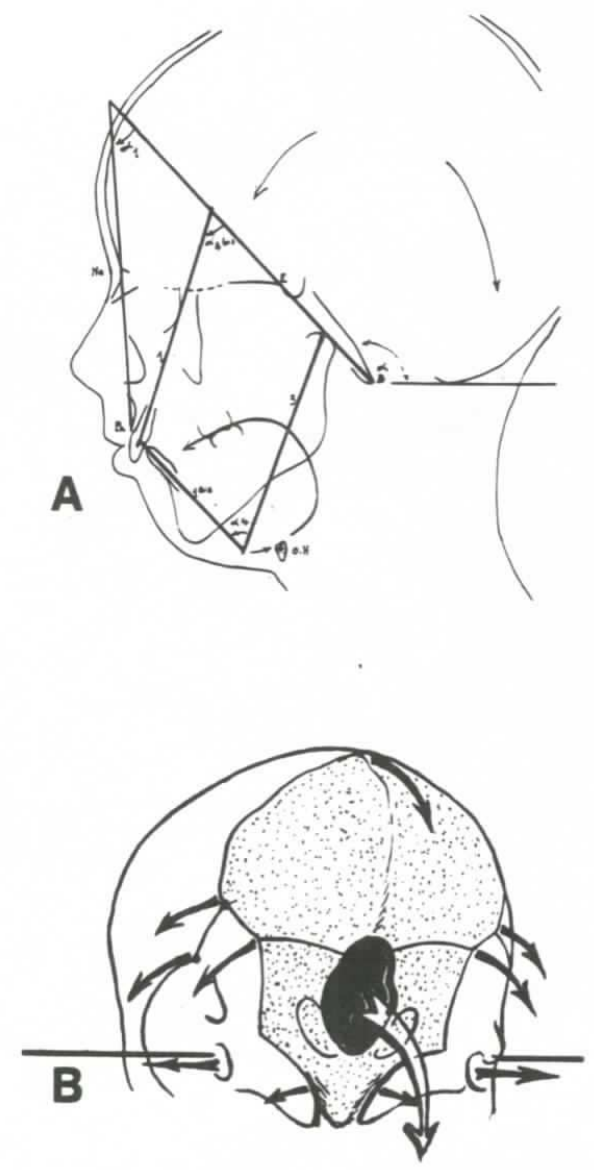

FIG. 2. Occipital flexion. (A) pantograph of Gudin. (B) The direction of the morphogenic changes in the occipital region in evolution from ape to man (after Delattre and Fenart, 1960)

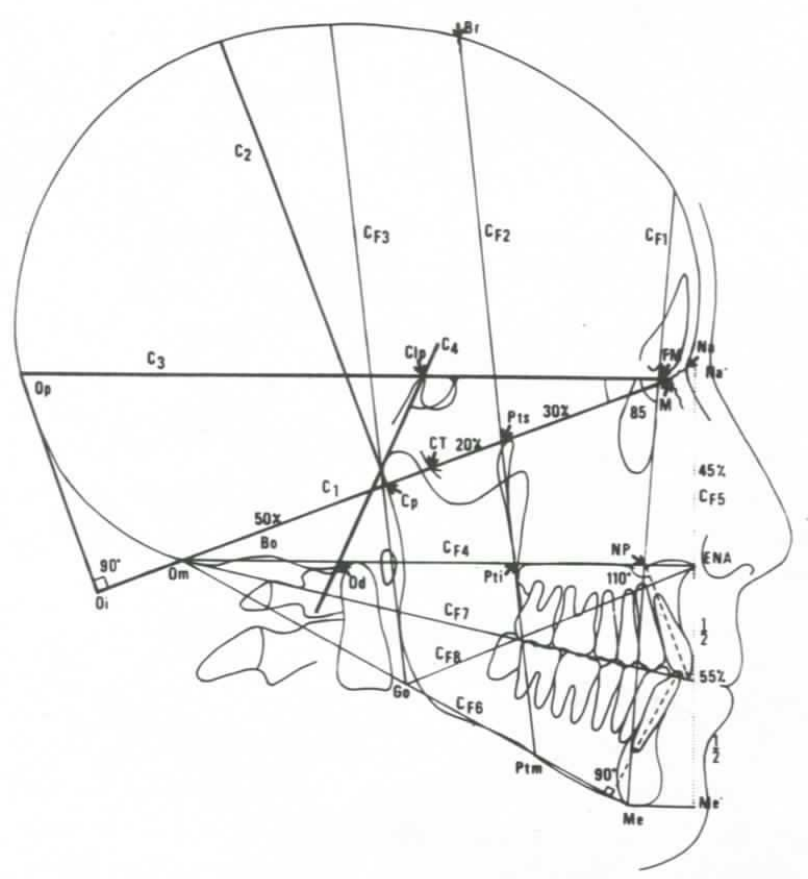

FIG. 3. Delaire analysis (after Delaire, modified by Deshayes, 1986). incorporates at least two developmental features, occipital flexion and the transversal growth of the fetal brain. During the fetal period, we see an important rotation of the anterior alveolar row in the transversal plane. The axis of this rotation lies near the canine alveolus (Fig. 8A). This generates the famous 'frontalization' of the incisivo-canine row, observed during hominization. This frontalization accentuates the development of the fossae mentales.

In short, we observe at birth the following ontogenic diagnosis (Fig. 8B): The symphyseal gap (the future trigonum mentale), the inclination of the mandibular symphysis, the fossae mentales and the alveolar frontalization are all results of neural rotation. This is accentuated by the growth of the fetal brain. The basal mandibular angle reflects the transversal growth of the brain during the fourth month.

Facial growth after birth has been widely studied in conjunction with dental development and the relative growth rates of the alveolar and basal parts. This rate difference generates a more or less prominent chin, the craniofacial system being to a large extent dominated in its variability by the phenomenon of craniofacial contraction. The variability in mandibular shape in humans can thus be understood in the light of craniofacial contraction. We now understand that variability in modern $H$. sapiens is the consequence of embryonic changes strongly rooted in evolutionary history, starting with the emergence of $H$. sapiens.

Permanent bipedalism impacts on the basal skull. However, it appears when the skull is already contracted and the foramen magnum is in the anterior position. Therefore, I have deduced that bipedalism is not the cause of the occipital flexion, but on the contrary is a consequence of embryonic changes.

To conclude, I have proposed that a fundamental dynamical phenomenon underlies primate craniofacial architecture, starting with embryogenesis. I call this phenomenon 'craniofacial contraction'. Occipital flexion has been well studied by many authors, especially by Delattre and Fenart (e.g., 1960). They have analyzed the pathways of different craniometric points such as bregma, lambda and inion in relation to the occipital kyphosis in $H$. sapiens and numerous primate species. They have shown systematic links between the pathways of the vault and the basal skull. When positive occipital flexion occurs, the vault grows from the facial to the occipital pole (Fig. 10). In all primates except $H$. sapiens, this flexion stops after birth, while the pathway changes and the direction becomes occipito-frontal. This reversal of occipital flexion is a well known event in the ontogeny of extant primates. There is no variability in the orientation of the growth vectors (see Delattre and Fenart, 1960 and references therein). Either occipital flexion occurs and the vault develops in the same direction, or flexion stops and the pathway of the vault reverses while the skull grows in extension.

\section{The Craniofacial Ontogenetic Organization Plan in Living} Non-Human Primates

Extant primates are organized on three levels of craniofacial contraction (Fig. 11), well differentiated at birth and especially in the adult mandible (Dambricourt Malassé, 1987). At birth, monkeys as well as great apes (Pan, Pongo, 

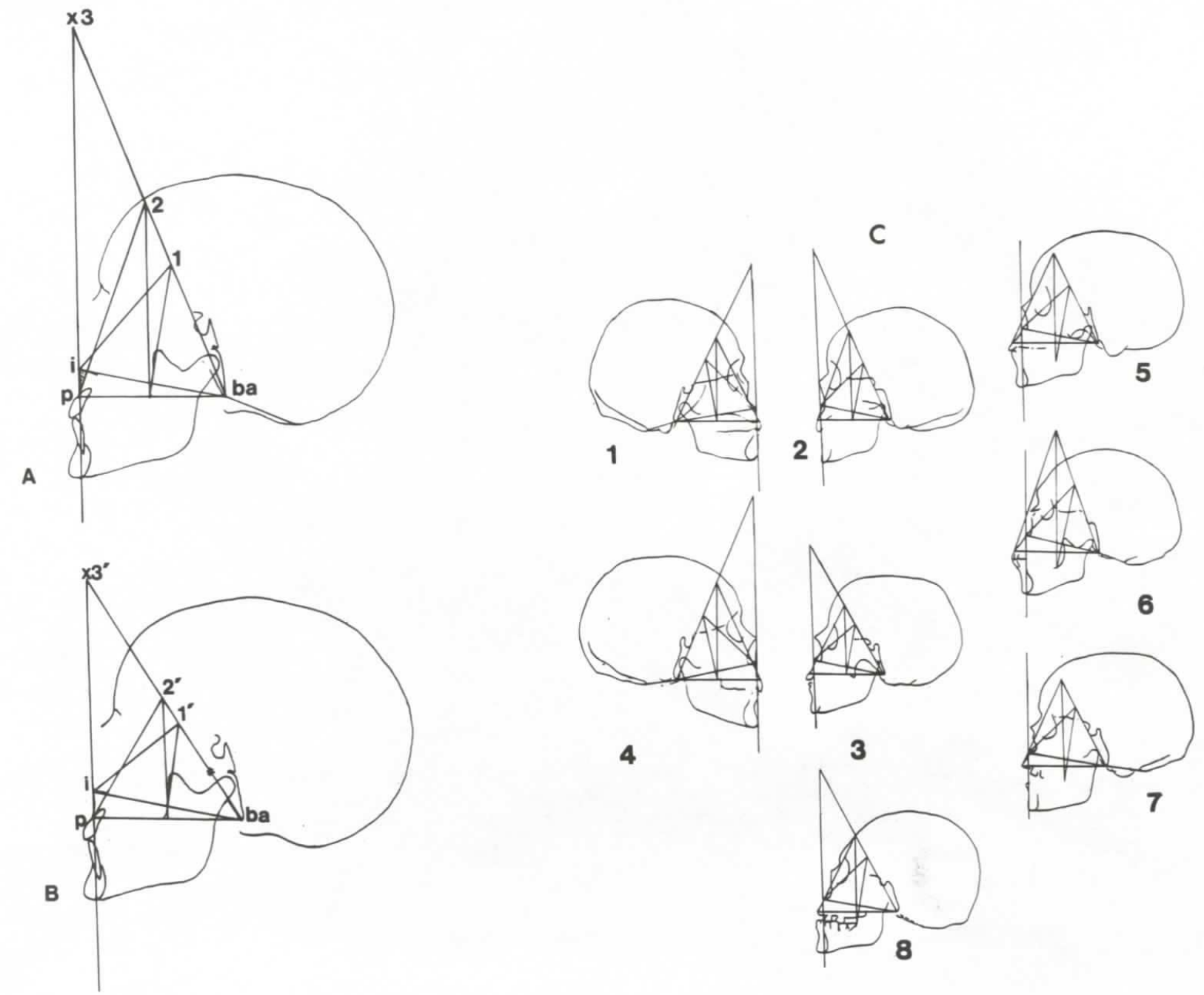

FIG. 4. Craniofacial architectural analysis. (A) using the great axis of the clivus (ba-x). Ba: basion, i: nasal spine, p: prosthion; (B) adapted to the study of fossil hominids, i.e. using the external section of the clivus, *: transverse tangent to the lamina medialis of the processus pterygoidei and to the pharyngeal slide of the spheno-occipital synchondrosis; (C) modern human variability, using the great axis of the clivus (after Gudin, 1954). (1) Tahitian, (2) Turkman, (3) Mandingue, (4) Armenian, (5) Soudan, (6) Australian, (7) Ethiopian, (8) Chuman indian.

Gorilla) differ in the value of the basal mandibular angle, which is $60^{\circ}$ in monkeys and $90^{\circ}$ in apes and H. sapiens. This is in accord with the longer duration of fetal brain growth in the latter. Craniofacial contraction is already less developed in the neonate pongid ( 8 months) as compared to the human fetus ( 8 months) (Fig. 12). This is seen at birth in the lack of a symphyseal gap (trigonum mentale) and of fossae mentales, a symphyseal inclination always greater than $90^{\circ}$ (Pan, Pongo $120^{\circ}$, Gorilla $127^{\circ}$ ), less marked alveolar frontalization and the weak premolar divergence. This lesser flexion is also found on the craniofacial vertical pantograph (Fig. 12). The symphyseal inclination increases during postnatal ontogenesis (Pan, Pongo $132^{\circ}$, Gorilla $135^{\circ}$ ), especially when occipital flexion stops at the age of three. The skull is no longer in contraction, but on the contrary is in extension (Fig. 10.1). The growth tempo of the manducator system is faster and consequently the basal mandibular angle closes more rapidly. The alveolar rows take the form of a ' $U$ ', whereas in H. sapiens they are more divergent (Fig. 13).

During the period of craniofacial contraction, monkeys and apes have a bipedal locomotion equilibrium. Later on, the craniofacial dynamics reverse and the locomotion equilibrium evolves towards a quadrupedal equilibrium, whatever the secondary type of locomotion (Michejda and Lamey, 1971).

A comparison between $H$. sapiens and apes shows that the former has longer ontogenic periods from fertilization onwards. Whereas craniofacial contraction stops in the apes, we find that in $H$. sapiens it continues until the adult stage. In each ontogenic phase, $H$. sapiens retains the early ontogenic events or anatomical characteristics, such as small canine tooth, craniofacial contraction, bipedalism, lack of supraorbital torus, lack of well developed manducator apparatus and a very long period of development of the brain, with an acceleration at the age of five (Saban, 1988). In the deciduous dentition, the first premolar develops five cusps, whereas it stops at two cusps in apes, with a small activation of growth of the vestibular cusp, which becomes more trenchant.

The data indicate that $H$. sapiens and apes do not share the same embryonic pathway. The growth tempo changes from fertilization and the entire ontogenesis is reorganized, especially in the cephalic pole, which is the first to differentiate. 
A

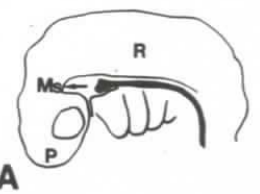

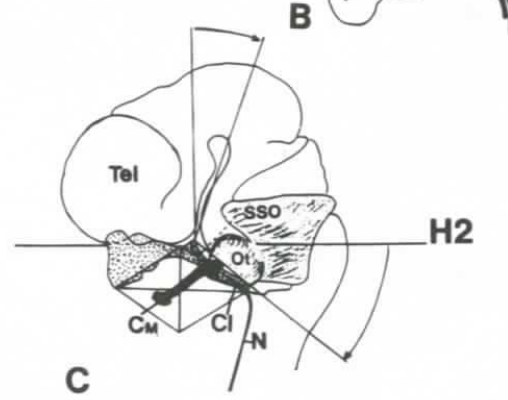

C

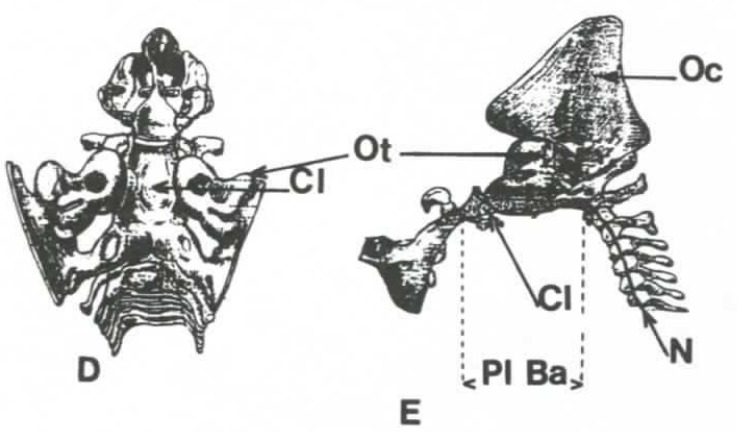

FIG. 5. Human neural tube (A, B, C) (A, B, from Müller and O'Rahilly, 1980b, C, from Lewis, 1920) and the embryonic chondrocranium (D, E) described in Lewis (1920). (A) stage 13; (B) stage 14; (C) stage 20. Neural tube: P: prosencephalon, R: rhombencephalon, Ms: mesencephalon, Mt: metencephalon, My: myelencephalon. Chondrocranium: $\mathrm{Cl}$ : clivus, $\mathrm{Cm}$ : Meckel's cartilage (mandible) Ot: otic capsule, PI. Ba: planum basale, Oc: occipital squama, S.S.O.: sphenoccipital synchondrosis. N: notochord. D: chondrocranium in superior view, E: chondrocranium in lateral view.

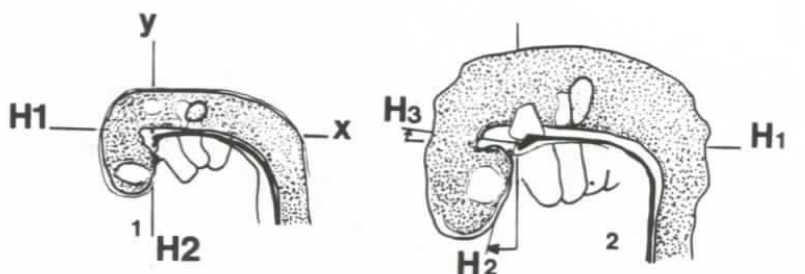

$\mathrm{H}_{3}$
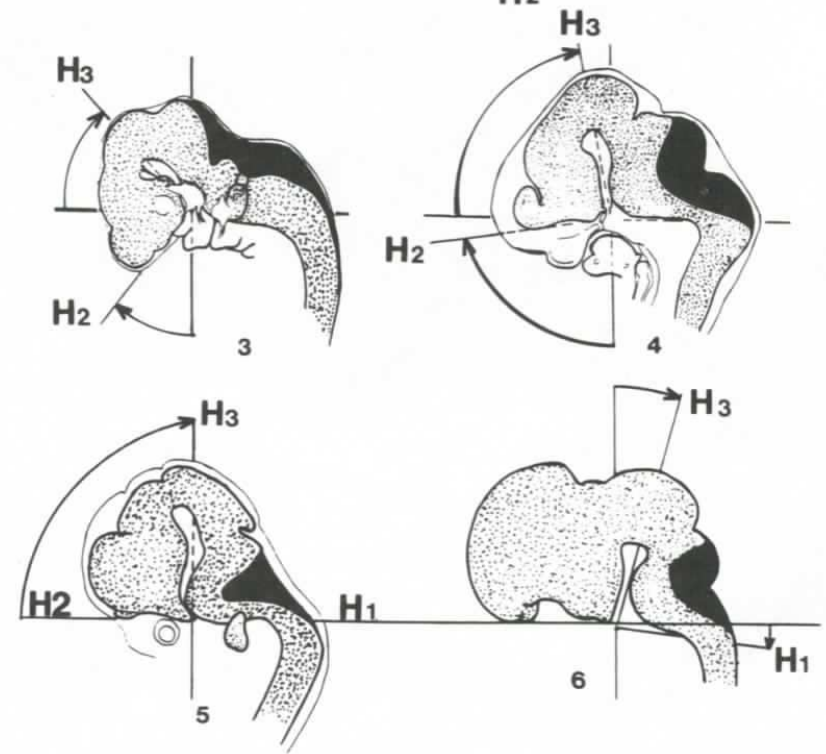

FIG. 6. Neural rotation and the cartesian axes. (1) stage 12; (2) stage 13; (3) stage 14: (4) stage 16; (5) stage 17 ; (6) stage 20 . Pars chordalis: H1, axis defined by the suprachordal neural floor. Pars praechordalis: H2, axis defined by the prosencephalic neural floor; $\mathrm{H} 3$, axis defined by the mesencephalic curvature. $Y$-axis: perpendicular axis to $X$ in the chordal apex. At first ((1) stage 12) $X$-axis $=\mathrm{H} 1, Y$-axis $=\mathrm{H} 2$. Progressively, the prosencephalon rotates (rotation of $\mathrm{H} 2$ and $\mathrm{H} 3$ ). After $90^{\circ}, \mathrm{H} 2=X$ and $\mathrm{H} 3=Y((5)$ stage 17). The rotation continues and $\mathrm{H} 1$ rotates: the occipital flexion begins.

A

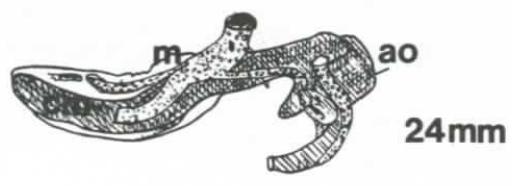

B

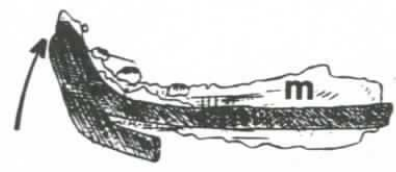

$30 \mathrm{~mm}$
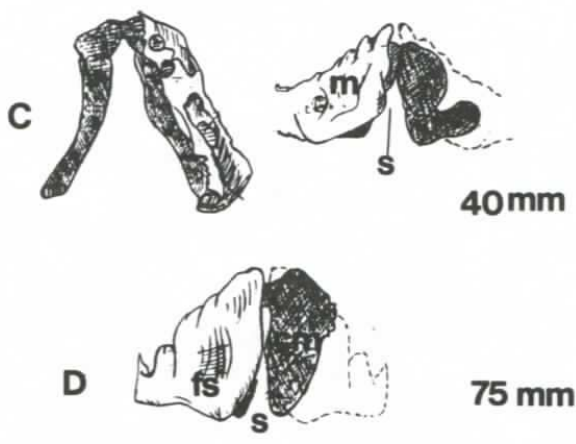

$75 \mathrm{~mm}$

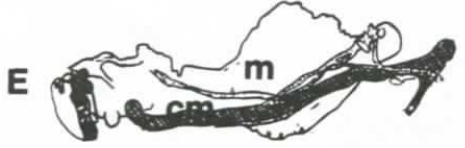

\section{$95 \mathrm{~mm}$}

FIG. 7. The cartilaginous mandibular skeleton. (A) lateral view (Low, 1910); (B) lateral view (Bolk, 1924); (C) superior and frontal view (Bolk, 1924); (D) frontal view (Bolk, 1924); (E) lateral view (Low, 1910). ao: auditory ossicles, cm: Meckel's cartilage, fs: fossae mentales, $\mathrm{m}$ : bony mandible, s: symphyseal gap. 


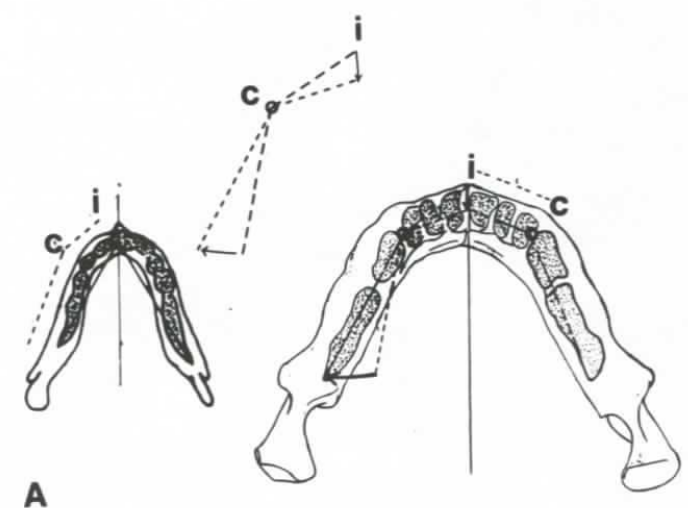

A

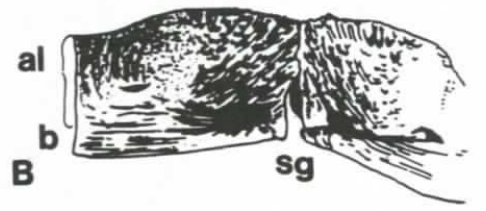

FIG. 8. (A) fetal alveolar frontalization between 3 and 9 i.u. months. C: canine alveolus, i: incisive alveoli, O: rotation axis. (B) frontal view of a neonate mandibule with the well differentiated alveolar (al) and basal (b) parts and the triangular symphyseal gap in the symphyseal axis (sg).

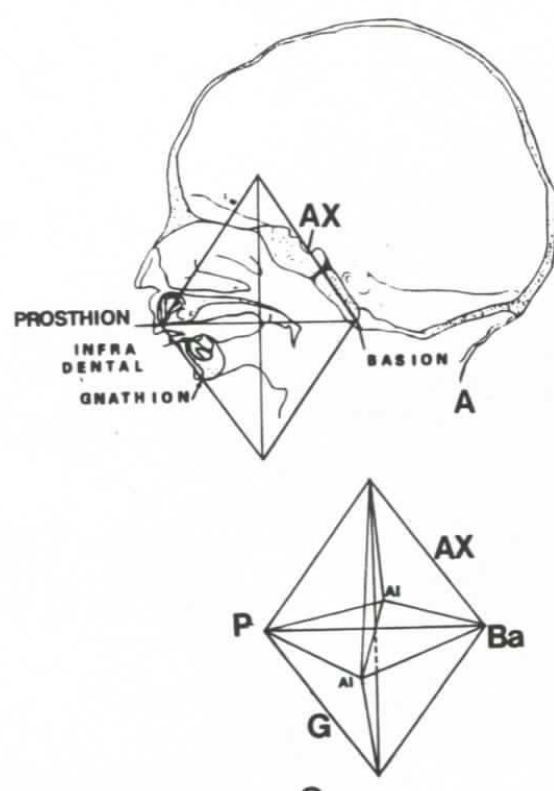

C
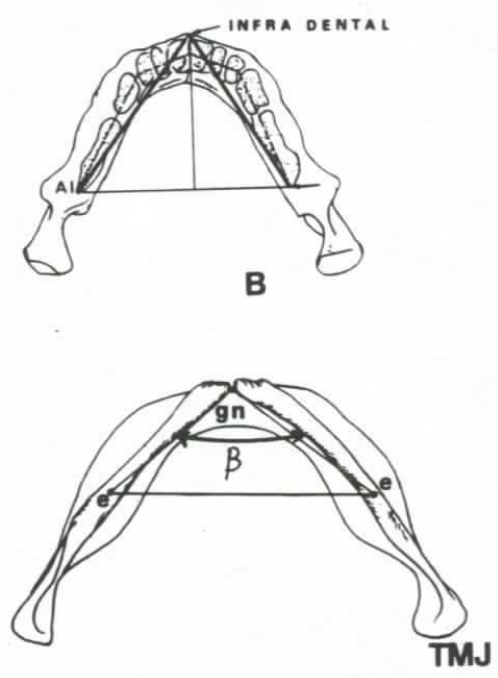

D

FIG. 9. The double pantograph. Human fetus (8 months), (A) sagittal section; (B) occlusal view; (C) double pantograph in 3D; (D) inferior view of the mandible. Al: posterior edge of the alveolar part, AX: great axis of the clivus, Ba: basion, : basal mandibular angle, e: basal notch, gn and G: gnathion, P: prosthion, TMJ: condyle of the temporomandibular joint. 


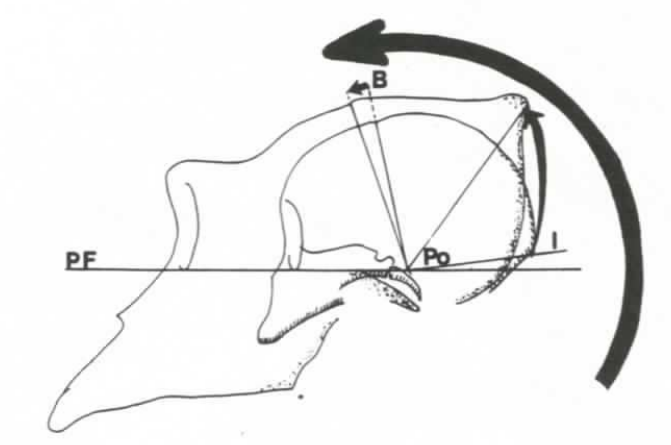

1

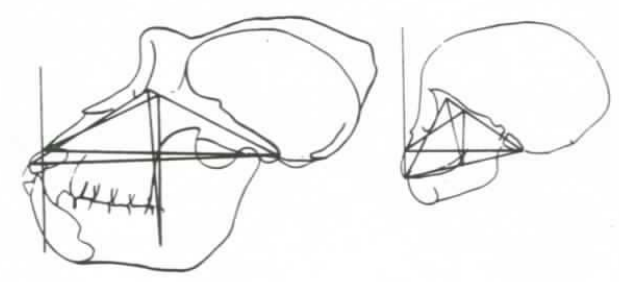

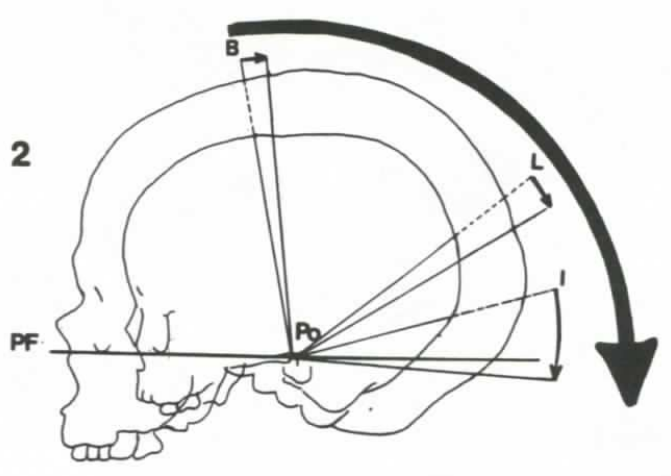

FIG. 10. Postnatal ontogenic pathways of the vault. (1) Gorilla, skulls in extension, opening of the pantograph, negative occipital rotation. (2) Homo sapiens, permanent occipital flexion. B: bregma, I: inion, L: lamda, Po: porion, PF: Frankfurt plane.

b

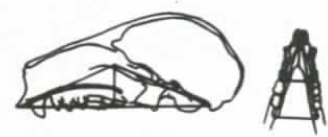

1 prosimians
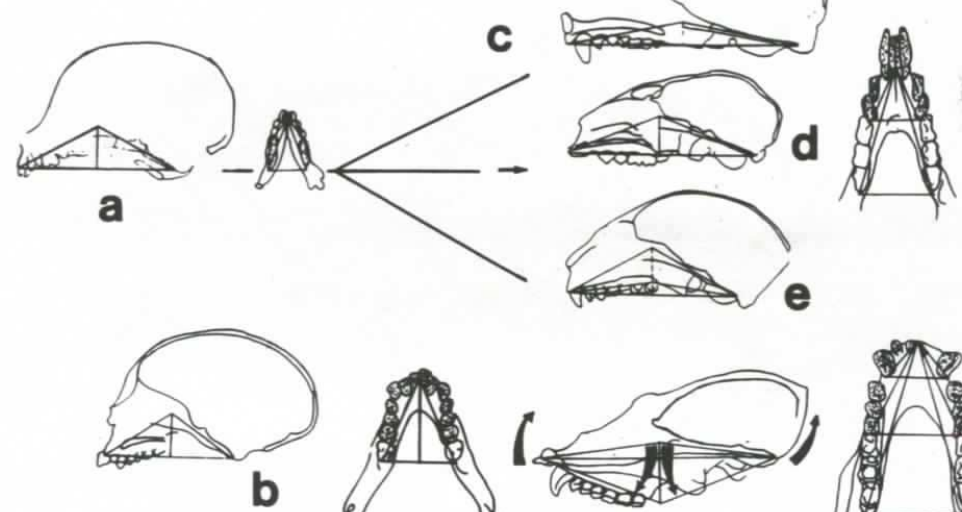

2 MONKEYS
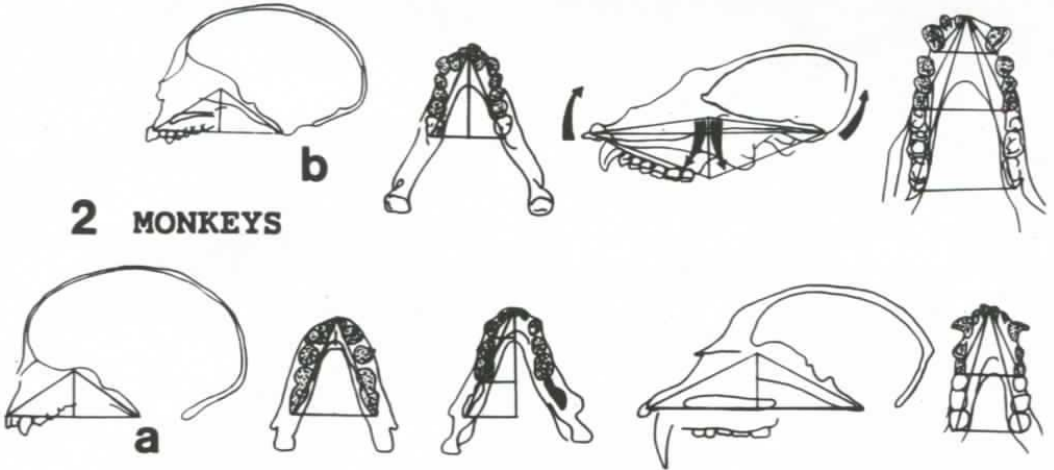

3 GREAT APES

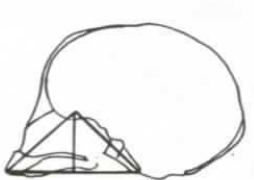

a

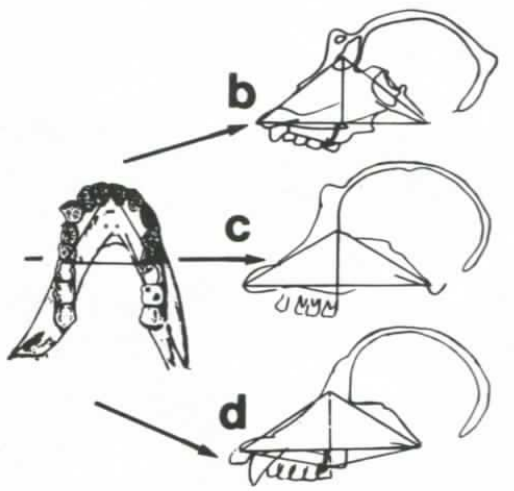

FIG. 11. The three levels of primate craniofacial contraction, cranial sagittal section and mandibular occlusal view. (1) Prosimians; a: neonate Indri, b: Lemur, c: Perodicticus, d: Hapalemur, e: Daubentonia. (2) monkeys, a: Cercopithecus infant and adult, b: Alouatta, infant and adult. (3) apes, a: neonate Gorilla, b: adult Gorilla, c: adult Pan, d: adult Pongo. 

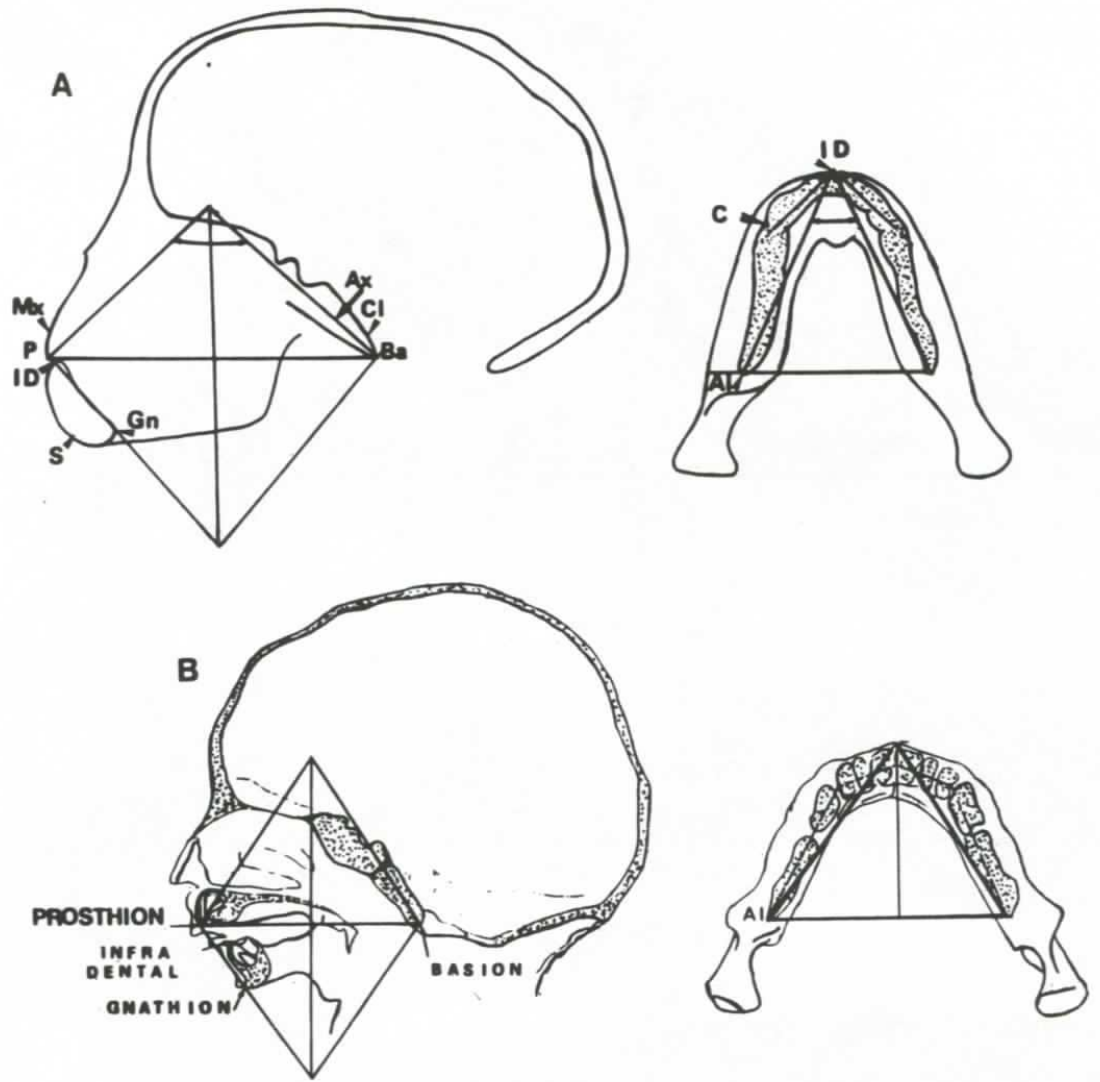

FIG. 12. Comparison between craniofacial sagittal sections of (A) Gorilla ( 8 months, neonate) and (B) a human fetus ( 8 months). Analysis of the craniofacial contraction with the double pantograph.
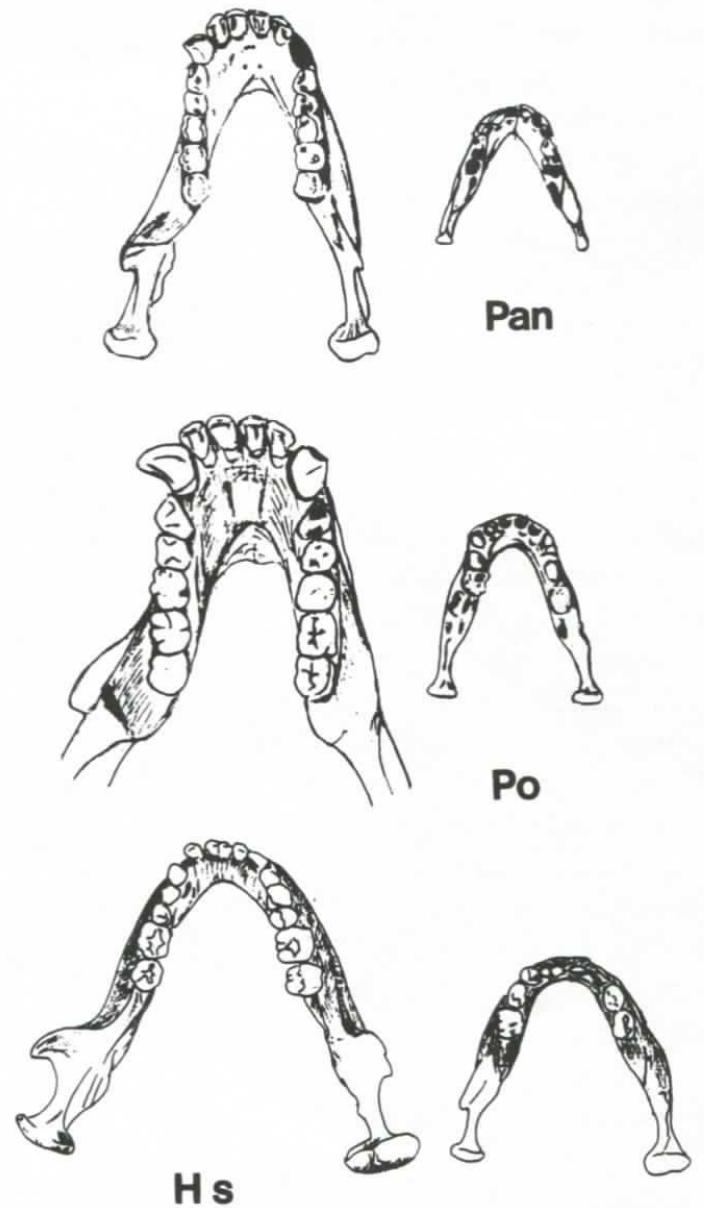

FIG. 13. Occlusal view of adult and infant mandibles of Pan, Pongo and Homo sapiens. 

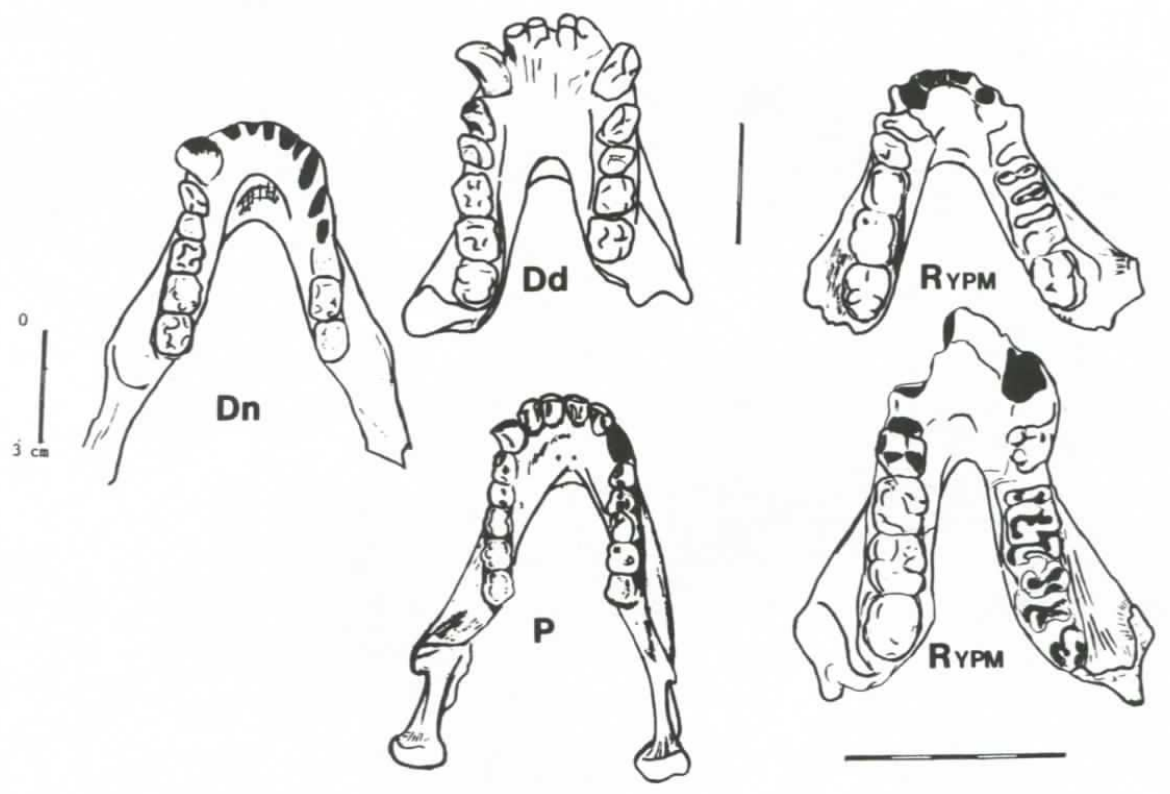

FIG. 14. Occlusal view of dryopithecine fossil mandibles compared with Pan (P). Dn: Dryopithecus nyanzae (Africa), Dd: Dryopithecus dryopithecus (Europe), R YPM: Rama-Sivapithecus (India).

\section{TEST OF THE PREDICTIVE THEORY}

When we formulate a hypothesis of how the embryonic plan of a modern ape can evolve into a human plan, we formulate an 'ex-post-predictive' theory, which will be tested by the study of paleontogeneses. First I will reconstruct a paleontogenesis based on fossils. Then I will observe whether the evolutionary changes among the paleontogeneses are in accord with the hypothesis.

In order to get from ape to man, the whole of the ontogenetic process, including embryogenesis, must be transformed. The rotation of the neural tube must be increased. During hominization we should find an evolutionary process of increasing craniofacial contraction coupled with an extension of the different ontogenetic periods beginning with embryogenesis.

We encounter the degree of craniofacial contraction of apes in Dryopithecus africanus, D. nyanzae, $D$. dryopithecus, Ouranopithecus, Ramapithecus and Gigantopithecus (Dambricourt Malassé, 1987) (Fig. 14). It has remained fundamentally unchanged over the last 20 million years up to the extant chimpanzee, gorilla and orangutan. The mandibular organization is stable. Thus, the ancestors of hominids had the same ontogenic bauplan as the living apes and I put forward the hypothesis that juvenile dryopithecines had a bipedal equilibrium. They lost it at the age of three whatever their permanent locomotion specialization was.

On a geological time scale we observe two other successive ontogenic levels after the emergence of apes and before that of Sapiens, namely the Australopithecus and Homo stages, which have subsequently disappeared.

Australopithecus: An Evolutionary Anatomo-Ontogenetic Discontinuity and the Origin of Permanent Bipedalism

For the first time in primate history, craniofacial contraction becomes permanent with Australopithecus (Fig. 15A),
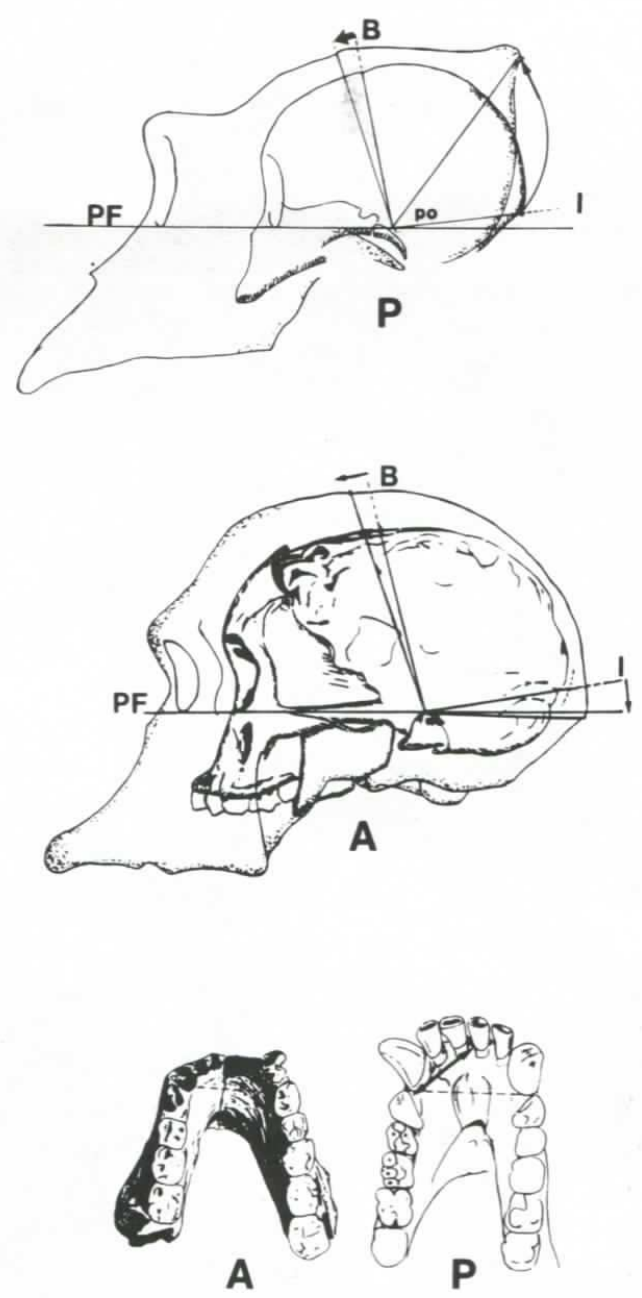

FIG. 15. Postnatal ontogenic pathways of the vault and associated mandibular alveolar arch. P: pongid, A: Australopithecus. B: bregma, I: inion, po: porion, PF: Frankfurt plane. 

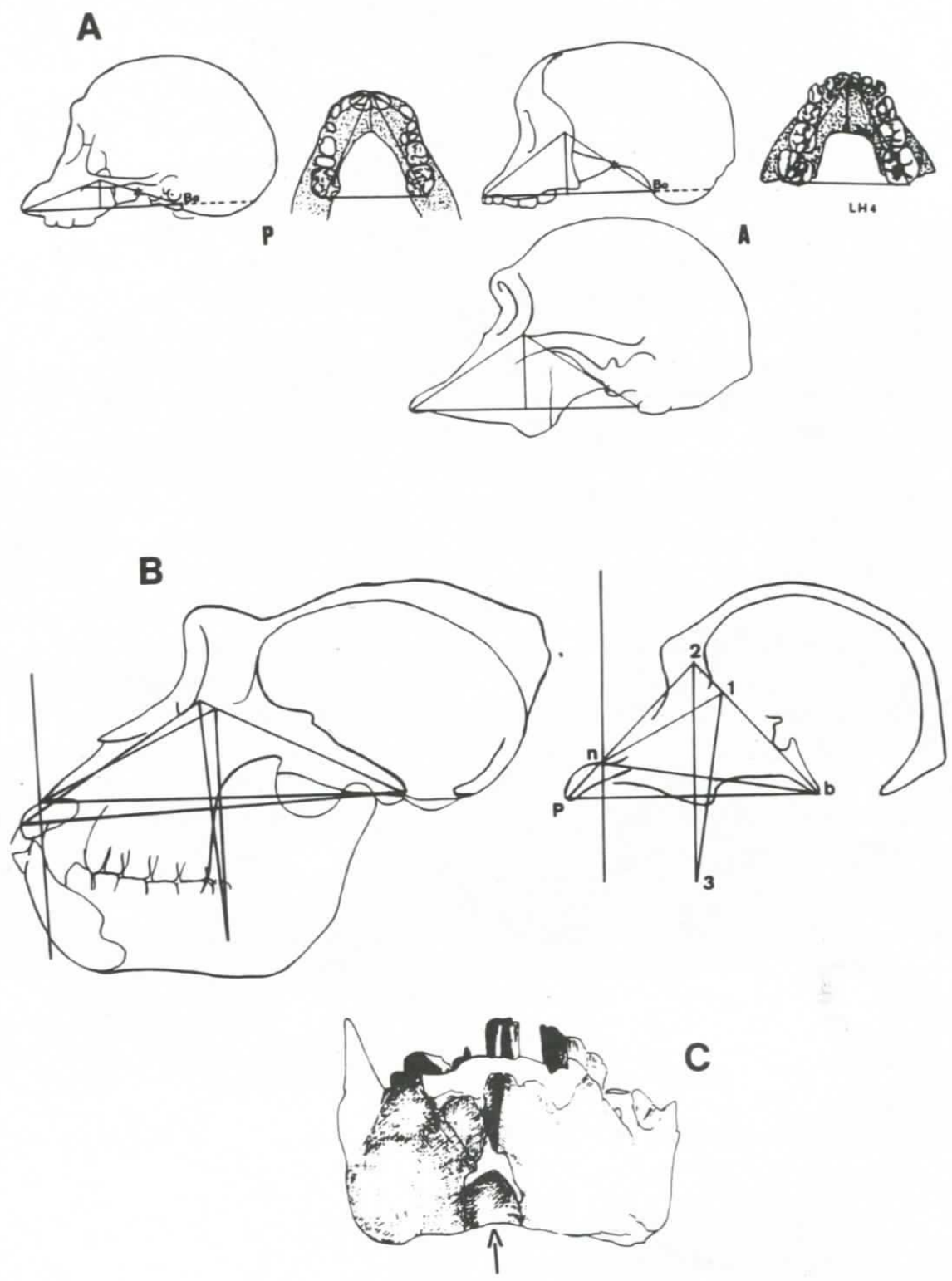

FIG. 16. Comparison between craniofacial contractions. (A) P, Pan stage M1 (first molar), A, Australopithecus. Taung (stage M1) and LH4 (stage M1), Sterkfontein (adult). The craniofacial contraction is analyzed starting from the external section of the basioccipital. The basioccipital flexion is evaluated by the line basion-(*). (B) comparison between Gorilla and Sterkfontein (classic great axis of the clivus).

(C) trigonum mentale (ER 729). The two analyses give the same results: Australopithecus is more contracted.

as is shown by the occipital flexion, which develops up to the adult stage (Rak and Howell, 1978; Dambricourt Malassé, 1987). Hence, the bipedalism of apes, formerly confined to the infant stage, becomes a permanent feature (Dambricourt Malassé, 1987, 1988). This hypothesis was recently reformulated by Masters et al. (1991).

For the first time a triangular gap emerges in the symphyseal area of the mandible (Fig. 16C), as is indicated by the trigonum mentale (Dambricourt Malassé, 1987; Wood, 1991). White and Johanson (1982) use the word mentum osseum, but this is not the anatomical chin. Thus, I deduce that neural rotation had already increased in Australopithecus, starting with the embryonic stage. This evolutionary event is an ontogenic discontinuity. We also observe numerous new ontogenic events: five cusps on the $\mathrm{dm} 1$ as in Sapiens, instead of two as in apes. The permanent canine grows with rather more infantile proportions and never approaches the large canine tooth with deep root seen in apes. The symphysis straightens up (the adult symphyseal angle is smaller, $105^{\circ}$ to $112^{\circ}$ instead of $130^{\circ}$ in fossil apes). The alveolar arch is subject to a greater frontalization, while the posterior rows diverge (Roth, 1983) in accordance with the greater craniofacial contraction (Fig. 15). We observe heterochronies: Taung is in the juvenile phase (M1 has erupted) but without the expected frontal growth towards the facial pole, or the growth of the supratoral ridge as in apes. This occurs, but only at a later stage (Fig. 15).

This new ontogenic organization can be understood as an extension and restructuring of the fundamental ontogenesis of apes. Undoubtedly, the embryonic unit formed by the cephalocaudal axis is reorganized, as shown in the studies of McHenry (1991) and Tardieu (1991). Some late growth inductions of the apes are still active, like the osteomuscular development and the facial growth vector of the frontal 
squama. However, we can no longer conclude that the face develops in typical pongid fashion (Bromage, 1987), since the fundamental basicranial context is a permanent contraction.

Australopithecus represents a new fundamental ontogenesis. Given the new ontogenic data, i.e. the reorganization of the cephalocaudal axis, the permanent craniofacial contraction and the reorganization of the telencephalon (Holloway, 1979), we conclude that Australopithecus from the point of view of its ontogenetic bauplan is not an anthropoid. It is a new ontogenic bauplan with many variabilities around the craniofacial phenomenon. The robust forms are very contracted, as is seen in the flattened face (Rak, 1985) and straightened clivus. We no longer see any change in the fundamental shape of the mandible. I deduce that the ontogenic time-lag observed between extant apes and Sapiens had begun with Australopithecus and that permanent bipedalism is a direct effect of this time-lag. The australopithecine emergence is an anatomo-ontogenic discontinuity in a continuous process of increasing instability, as evidenced by the amplified craniofacial contraction and the prolonged ontogenic tempo. I do not support the hypothesis of an initial relationship between permanent bipedalism and environmental changes, such as the decrease in forest cover (Rift Valley theory of Coppens, 1983). I believe that permanent bipedalism, i.e. the fundamental locomotion equilibrium on the ground, could have emerged in the forest environment. Senut $(1982,1991)$ has shown that early australopithecines were still arboreal. I have put forward the hypothesis that permanent bipedalism represents an effect of inner ontogenetic strains closely linked to embryonic dynamics. It has nothing to do with a locomotory specialization. Permanent bipedalism is a fundamental locomotion equilibrium, as is a quadrupedal equilibrium. The difference from apes is the duration of these locomotion dynamics during ontogenesis. These dynamics become permanent in association with the craniofacial contraction beginning with Australopithecus, whereas they are merely temporary in apes. Permanent bipedalism should and could have existed before the decrease in forest cover.

\section{Homo habilis, Homo erectus and Neanderthals}

The craniofacial amplitude increases still more with Homo habilis and $H$. erectus. The architectural analysis of their skulls (Fig. 17) shows that the ontogenesis was slightly longer than in australopithecines, i.e. the pathway of the ontogenic phenomenon has not changed, but its amplitude is

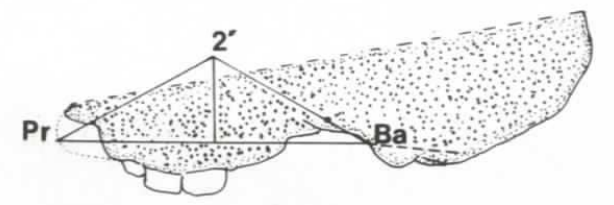

SK 47

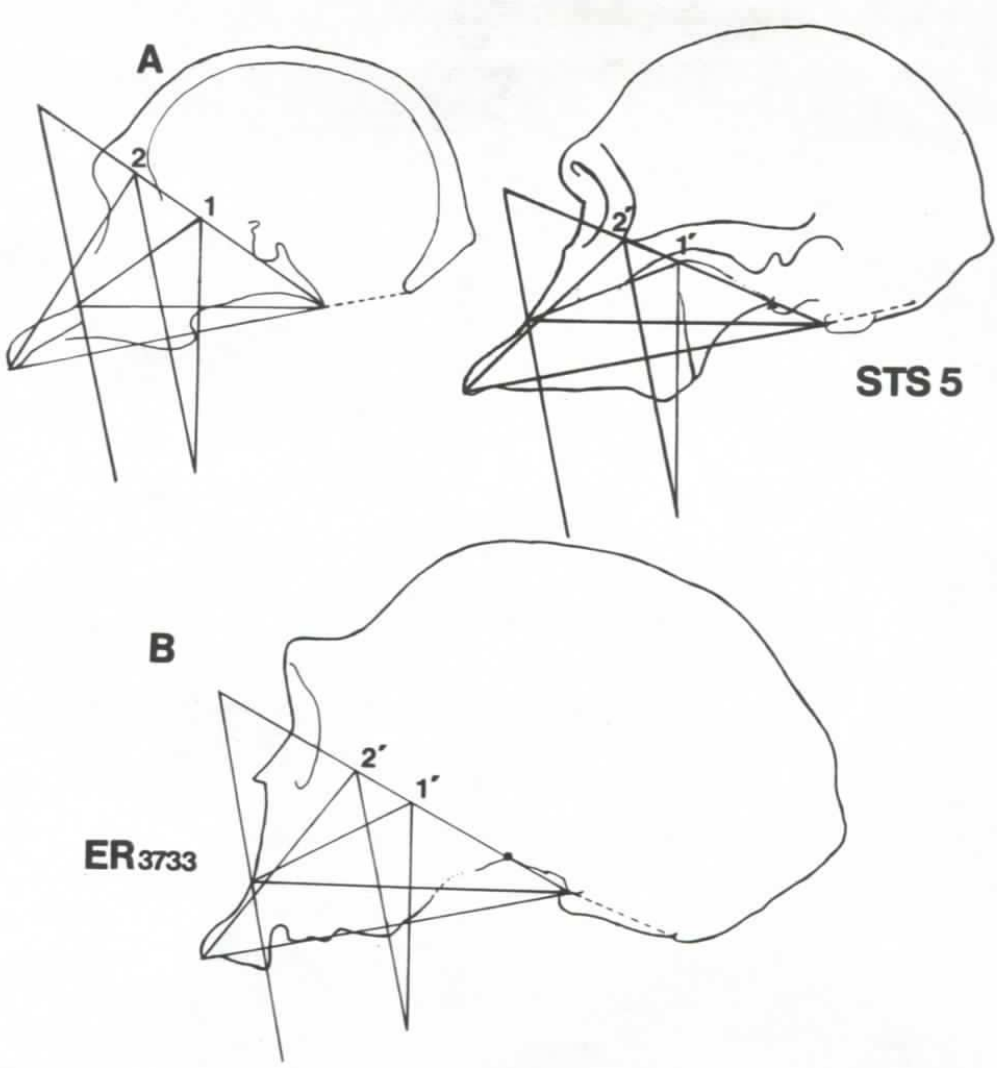

FIG. 17. Comparison between contractions of Australopithecus and Homo. Two analyses, one with the great axis of the clivus (sections 1,2 ) one with the external face (sections 1', 2'). Australopithecus: SK 47 (prosthion reconstructed on the cast), Sts 5; Homo: ER 3733. The two analyses show the same result: Homo is more contracted. 
greater. This represents an extension of the duration of the embryonic neural rotation.

The craniofacial and mandibular organization represents a new degree of contraction with numerous associated evolutionary trends. This new ontogenic pattern is longer, in accordance with the increasingly complex nature of the neural and vascular tissues (Tobias, 1967, 1971, 1983, 1987; Holloway, 1979, 1982; Saban, 1977a,b, 1990) and the decreasing growth tempo of the manducator system. This is evidenced by the disappearance of the facial growth vector of the frontal squama (Fig. 18B). This vector remains oriented towards the occipital pole as in the infant phase. The retardation is also observed in a larger basal mandibular angle, similar to that of modern man and a narrower post-orbital constriction. The alveolar arch is more divergent $(H$. habilis ER 992, ER 730, ER 820, OH 22, OH 7 and $\mathrm{OH} 13$ reconstructed by symmetry). The older skulls are more difficult to study on account of the poor preservation of the basicranium (ER 1470, ER 1883). The great inclination of the clivus in $\mathrm{OH} 24$ is not in accord with the maxillary prognathism. On the other hand, the relatively well preserved skull ER 3733 is coherent (Fig. 19). Neither mandibular nor neural bones possess Sapiens characters. There is no chin, nor fossae mentales. The occipital flexion is less developed, the craniofacial contraction is less marked, the supraorbital torus is preserved, there is no frontal curvature, the rolling up of the brain is not similar to that in Sapiens and there are many fewer anastomoses in the cephalic vascularization (Saban, 1984; Grimaud Hervé, 1991). All this reflects the degree of functional complexity of the brain.

There is no difficulty in defining the ontogenic bauplan of Neanderthal man. The craniofacial architecture demonstrates that its fundamental ontogenesis is the same as in $H$. erectus
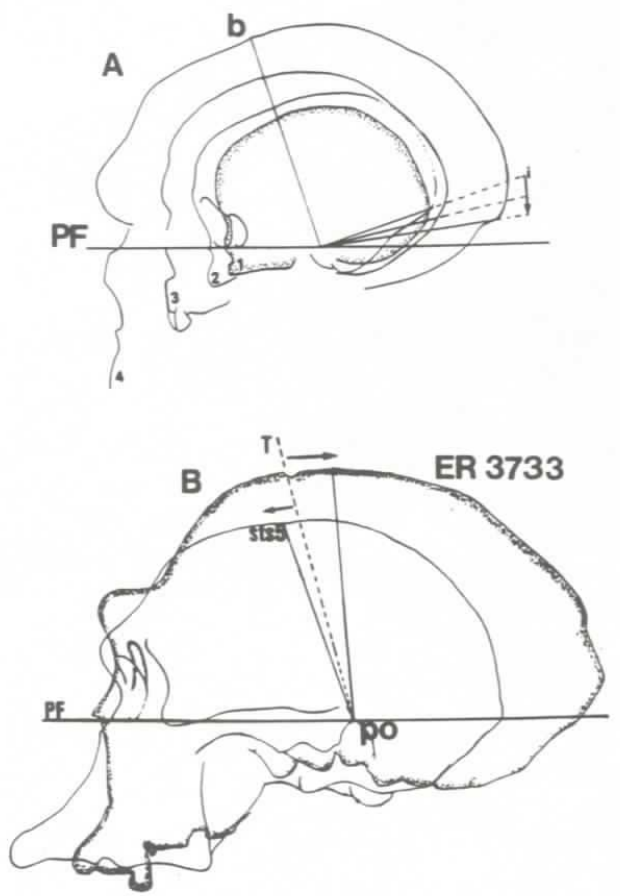

FIG. 18. Frontal growth vector. (A) Homo neandertalensis (except 1, Sapiens fetus), frozen bregma. (B) negative pathway Taung (T)-Sterkfontein, positive pathway Taung-Homo (ER 3733). Taung represents the common primate juvenile position.

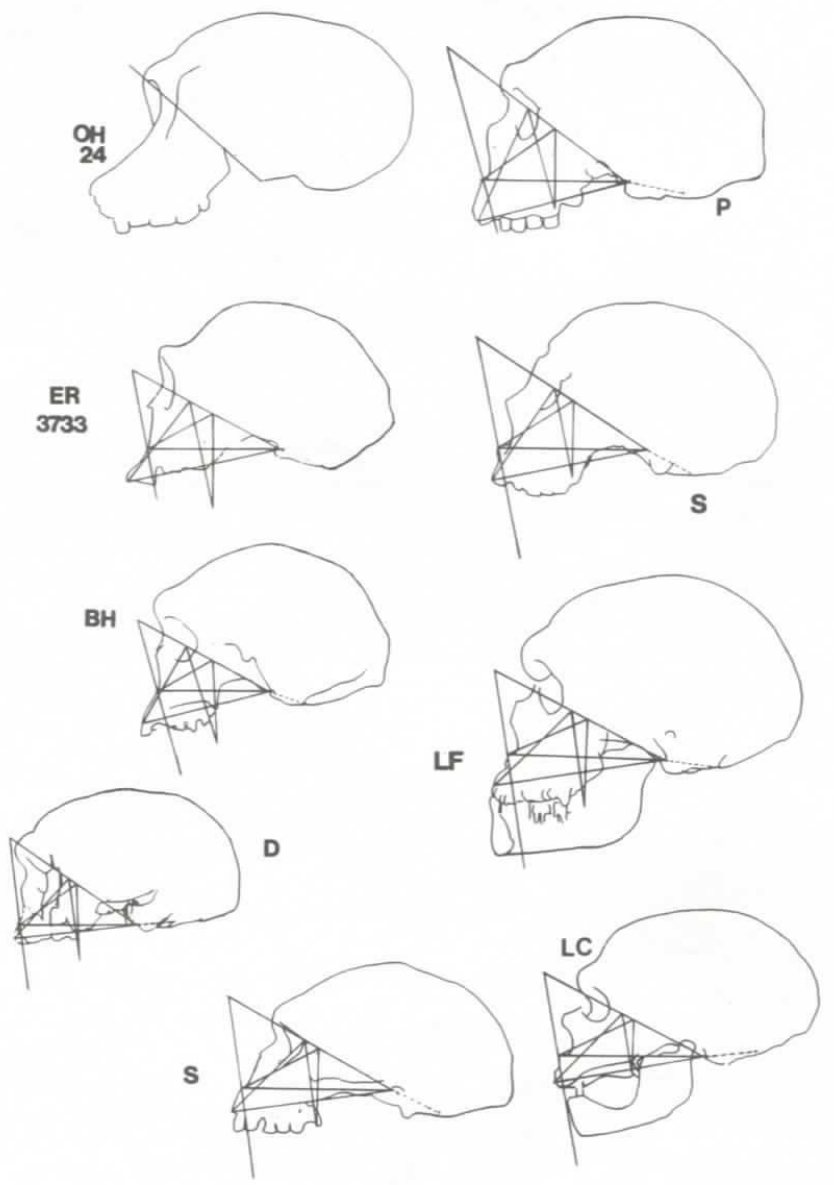

FIG. 19. Analysis of craniofacial contraction in Homo, using the external face. Africa: OH 24, ER 3733, BH (Broken Hill), Asia: D, Dali, S: Sangiran 17, Europe: P, Petralona, S: Saccopastore, LF: La Ferrassie, LC: La Chapelle aux Saints.

(Fig. 19) and very different from that of Sapiens (Fig. 20). (I here use the name $H$. erectus to define an ontogenic bauplan and not to describe an historical and geographical human species.) This chronological biological unit disperses in the Old World and fluctuates as a function of embryonic dynamic factors. Neanderthal man is the result of such a process. He represents a slowdown of the $H$. erectus embryonic craniofacial contraction, as proved by the conservation of embryonic meningeal vessels such as Breschet's sinus (Saban, 1984, 1990) and the weak degree of craniofacial contraction. The well known extension of the face is the result of a slowdown of occipital flexion within the ontogenic parameters of $H$. erectus. I correlate this slowdown with the halting of the frontal growth vector in the infantile position (Dambricourt Malassé, 1987) (Fig. 18A) and the evolutionary impoverishment of the meningeal vascularization (Saban, 1984; Grimaud Hervé, 1991). Maureille (1992) has shown that the premaxillary sutures are still active in the infant Neanderthal, while they are already ossified in a newborn Sapiens. I interpret this activity as being an effect of the global slowing down of the craniofacial contraction specific to the embryonic development of $H$. erectus. This sort of phenomenon, with craniofacial elongation and frozen frontal growth, is observed in China with Dali (frozen bregma) and probably in the very elongated skulls of Yuxian II (Pope, 1992) or Sangiran 17 (Indonesia) (Fig.19). 

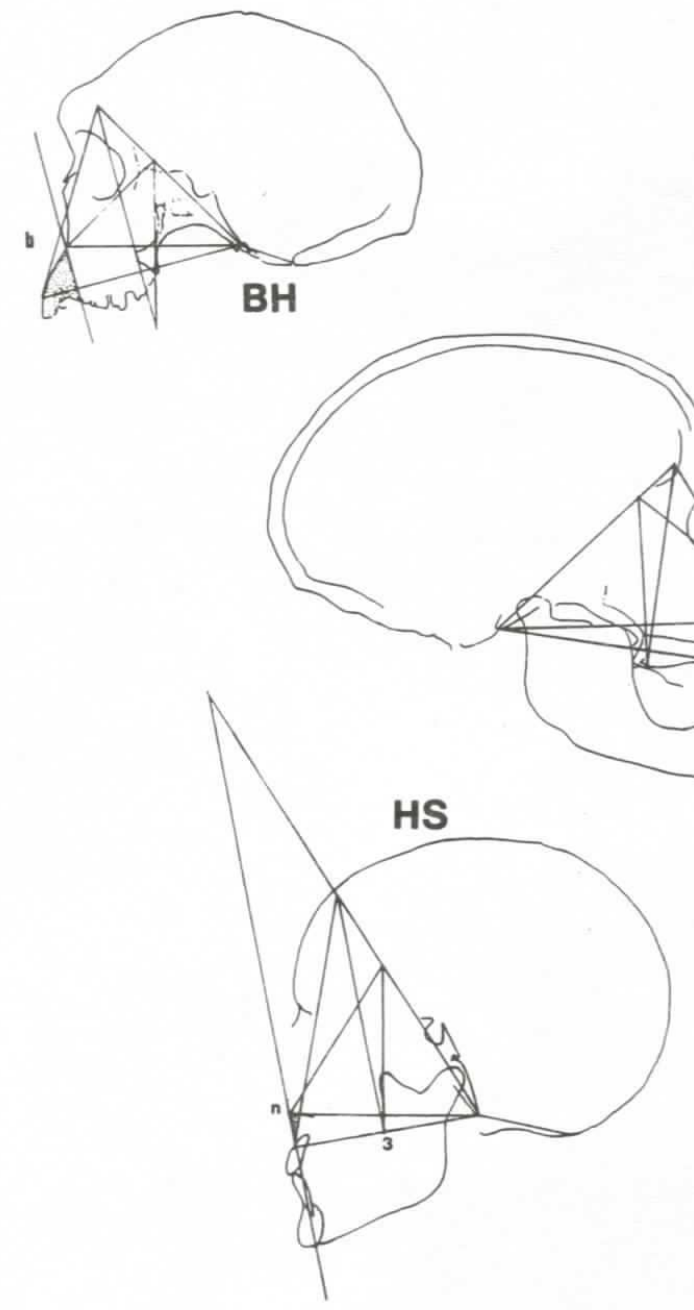

FIG. 20. Comparison between the contracted skull of Sapiens (HS), the elongated skull of Neanderthal Man $(\mathrm{N})$ and the Homo erectus organization of Broken Hill (BH).
Thus, we cannot conclude that the evolution of the increasing volume of the telencephalon (Leigh, 1992) represents a pathway to Sapiens. Neandertalization, from Mauer to Saint Césaire, never reaches the ontogenic organization of Sapiens. The notion of european archaic $H$. sapiens lacks ontogenic logic. Sapiens represents the opposite evolutionary trend. He corresponds to an ontogenic discontinuity, i.e. the third threshold of hominization (Fig. 21). In this regard, neandertalization is a microevolution of the $H$. erectus ontogenic bauplan, whereas sapienization is a macroevolution of $H$. erectus ontogenic bauplan. Sapiens is able to associate the complexity of the telencephalic vesicles with its cephalic network, i.e. sutural activities, meningeal vascular tissues and flexion of the chondrocranium. As a consequence, Neanderthal man and Sapiens belong to two distinct basic ontogeneses which derive from different evolutionary embryonic pathways. Therefore I have excluded the word sapiens from Neanderthal taxonomy (Dambricourt Malassé, 1987) as did Saban (1984), Heim (1988) and more recently Stringer (1990).

\section{CONTINUITY AND DISCONTINUITY IN HUMAN EVOLUTION}

To conclude, no ontogenic data support the hypothesis that there existed in Europe a gradual macroevolution towards Sapiens before the first stage of Neanderthal man was reached. In the light of my analysis, there is no such thing as archaic $H$. sapiens. This was a concept imposed by the idea that evolution is always gradual at the macro-level.

Hominization enters into the category of macroevolutionary processes. The tempo at which this evolution takes place is in constant acceleration and ahead of speciation, since no speciation had sufficient time to occur within the $H$. erectus

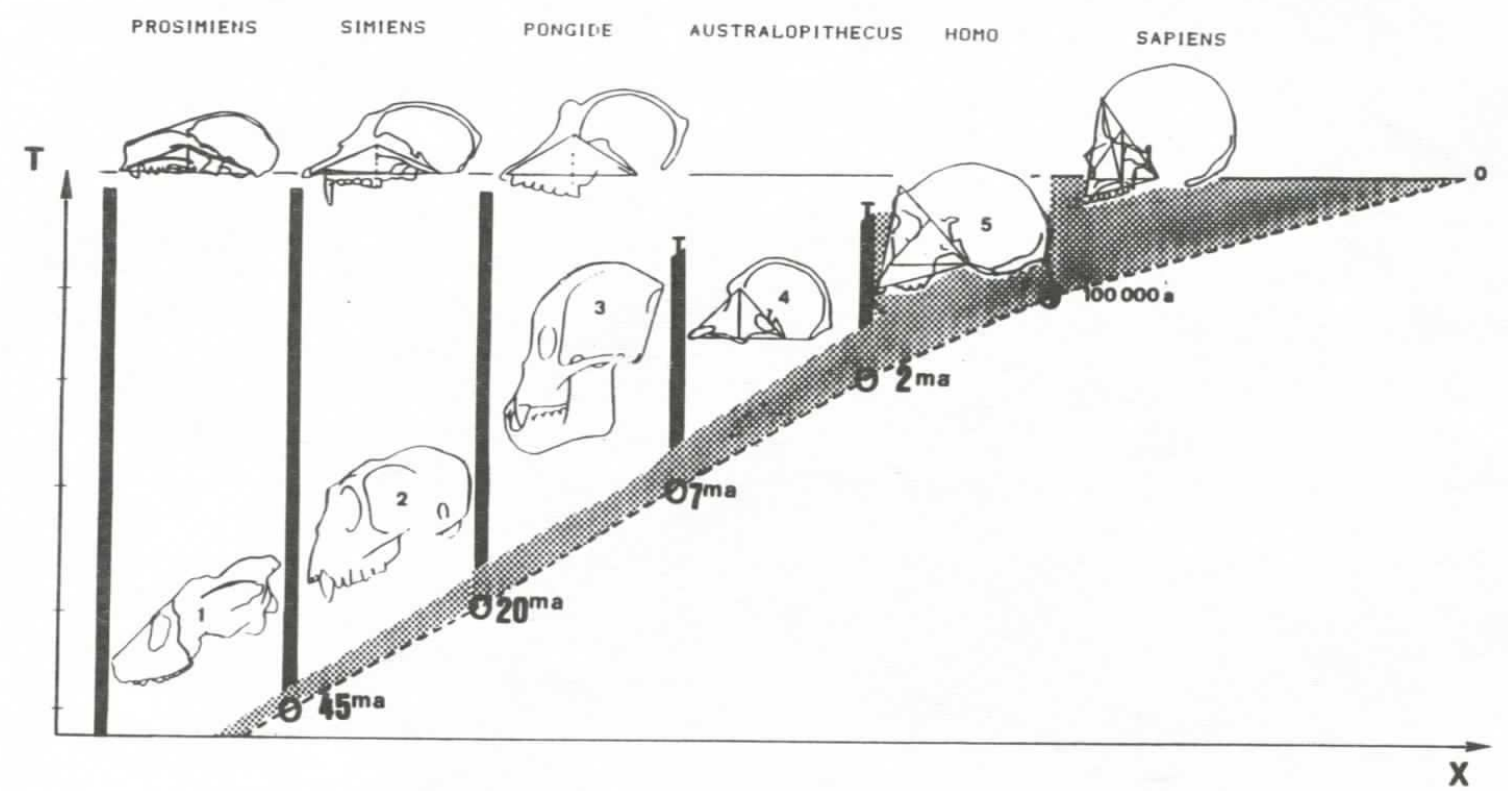

FIG. 21. The phylogeny of the craniofacial contraction, showing micro- and macroevolution. T: time, X: instability of the ontogenic craniofacial biodynamics (telencephalization, contraction). ma : million years, 1: Adapiform, 2: Mesopithecus, 3: Proconsul africanus, 4 : Australopithecus (Sterkfontein 5), 5: Homo (Broken Hill). O: threshold of instability leading to macroevolution. 
ontogenic bauplan (Fig. 21). In this perspective Sapiens is a fundamental ontogenesis. Hominization represents a continuous process in acceleration with regards to its cause, namely an increasing instability, but it is discontinuous in its effects, i.e. the ontogenic organizations, with three thresholds, Australopithecus, Homo and Sapiens.

\section{ACKNOWLEDGEMENTS}

I would like to thank Dr. Jean Chaline for inviting me to the workshop on 'Modes and Tempos of Evolution in the Quaternary' and to Dr. Lars Werdelin for editorial help and for improving the English.

\section{REFERENCES}

Anthony, J. (1952). Influence des facteurs encéphaliques sur la brisure de la base du crâne chez les Primates. Annales de Paléontologie, 53, 67-79. Ashton, E.H. and Zuckerman, S. (1956). Age changes in the position of the foramen magnum in Hominoids. Proceedings of the Zoological Society, London, 126, 315-325.

Bolk, L. (1909). On the position and displacement of the foramen magnum in the Primates. Proceedings of the Section of Sciences, Koninklijke Nederlandse Akademie Van Wetenschappen te Amsterdam, 12, 362.

Bolk, L. (1924). Die Entstehung des Menschenkinnes. Ein beitrag zur Entwicklungsgeschichte des Unterkiefers. Verhandelingen der Koninklijke akademie van wetenschappen, Amsterdam, Sect. 2, B 83, 5, $1-106$.

Bolk, L. (1926). Le problème de l'Anthropogenèse. Compte Rendu de l'Association des Anatomistes, 1, 80-92.

Bromage, T.G. (1985). Taung facial remodeling: A growth and development study, In: Tobias, P.V. (ed.), Hominid Evolution: Past, Present and Future. pp. 239-245, Alan R. Liss, New York.

Bromage, T.G. (1987). The biological and chronological maturation of early hominids. Journal of Human Evolution, 16, 257-272.

Bromage, T.G. (1989). Ontogeny of the early hominid face. Journal of Human Evolution, 18, 751-773.

Choukroun, G. (in press). Compte Rendu de la réunion du Club Télécrâne International du 28 nov. 1992, Cité des Sciences, Paris. La Lettre de S.O.S. Ortho.

Condemi, S. (1991). Circeo I and variability among classic neandertals. In: Istituto Poligrafico e zecca dello stato (ed.), The Circeo I neandertal skull. Studies and Documentation, pp. 339-355. Roma.

Coppens, Y. (1983). Le singe, l'Afrique et l'homme, Paris, Fayard, 148 pp.

Courtot, D. (in press). Crânexplo: une nouvelle exploration de l'Homme. Ortho-scoop.

Dambricourt Malassé, A. (1987). Ontogenèses, paléontogenèses et phylogenèse du corps mandibulaire catarhinien. Nouvelle interprétation de la mécanique humanisante (théorie de la foetalisation, Bolk, 1926) Thése de Doctorat Museum National d'Histoire Naturelle, Paris, 426 pp.

Dambricourt Malassé, A. (1988). Hominisation et foetalisation Comptes Rendus de l'Académie des Sciences, Paris, 307, 199-204.

Dambricourt Malassé, A. (1992a). Droit de réponse. Revue d'O.D.F., 26, 71-79.

Dambricourt Malassé, A. (1992b). L'hominisation et la théorie des systèmes dyamiques non-linéaires (Chaos). Revue de Biomathématique, 117, 5-32, $118,5-48,119,5-54$

Dambricourt Malassé, A. and Deshayes M.J. (1992). Modeling of the craniofacial architecture during ontogenesis and phylogenesis. In: Berthoz, A., Graf, W. and Vidal, P.P. (eds), Head-Neck Sensory-Motor System, pp. 36-46, Oxford University Press, New York and Oxford.

Dechambre, E. (1948-49). L'évolution des Primates et la théorie de la foetalisation. Mammalia, 12, 27-41, 13, 100-117.

Delaire, J. (1978). L'analyse architecturale et structurale cranio-faciale (de profil). Revue de Stomatologie, 79, 1-33.

Delaire, J., Schendel, S. and Tulasne, J.F. (1981). An architectural craniofacial analysis: a new lateral cephalometric analysis. Oral Surgery, 52, 226-238.

Delattre P. and Fenart, R. (1960). L'Hominisation du crâne. CNRS, Paris, $418 \mathrm{pp}$.

Deshayes, M.J. (1986). Croissance cranio-faciale et orthodontie, Masson, Paris, $87 \mathrm{pp}$.

Deshayes, M.J. (1988). La biodynamique cranio-faciale. Revue d'Orthopédie Dento-Faciale, 22, 283-298.
Deshayes, M.J. (1991). Reconsidération de la croissance craniofaciale au cours de l'ontogenèse et de l'évolution. Implications pour les traitements orthopédiques. Revue d'Orthopédie Dento-Faciale, 25, 353-365.

Deshayes, M.J. (in press, a). Vers un nouveau procédé biométrique de modélisation des anomalies de la morphologie crânienne et faciale. Cahier d'Anthropologie et Biométrie humaine.

Deshayes, M.J. (in press, b). La croissance cranio-faciale: une suite de processus complexes. Le concept de biodynamique cranio-faciale. Les Cahiers de Stomatologie et de Chirurgie maxillo-faciale.

Deshayes. M.J. and Dambricourt Malassé A. (1990). Analyse des différents types architecturaux cranio-faciaux par l'approche ontogénique de l'hominisation. Revue de Stomatologie, 91, 149-258.

Deshayes, M.J., Dambricourt Malassé A. and Deshayes P. (1992). Utilisation de la téléradiographie dans la compréhension de la mécanique humanisante. In: C.T.H.S. (ed.), L'Image et la Science, $115^{\circ}$ Congrès nationale des Sociétés, pp. 149-157.

Devaux, E. (1921). L'infantilisme de l'Homme par rapport aux Anthropoides et ses conséquences. Revue générale des Sciences, 32, 276-280.

Godard, B. and Ducasse, D. (1973). L'examen radiologique en O.D.F L'analyse de Gudin. Revue d'Orthopédie Dento-Faciale, 7, 373-392.

Gould, S.J. (1977). Ontogeny and Phylogeny. Harvard University Press, Mass, Cambridge, $501 \mathrm{pp}$.

Grimaud Hervé, D. (1991). L'évolution de l'encéphale chez l'Homo erectus et l'Homo sapiens. Ph.D. thesis, Université de Provence-Aix Marseille, 1,925 pp.

Gudin, R.G. (1952). Etude du crâne de profil. Morphologie et radiographie. Bulletin de la Société d'Anthropologie, Paris, 3, 59-87.

Gudin, R.G. (1954). Etude du crâne du profil. Morphologie et radiographie. Bordeaux, France, 73 pp.

Heim, J.L. (1982). Les enfants néandertaliens de La Ferrassie. Etude anthropologique et ontogénique des Hommes de Néandertal. Masson, Paris, $169 \mathrm{pp}$.

Heim, J.L. (1988). L'Homme de Néandertal (Homo presapiens neandertalensis) et les racines d'Homo sapiens en Europe. In: Fondation Singer-Polignac (ed.), L'Évolution dans sa Réalité et ses Diverses Modalités, pp. 179-211. Masson, Paris.

Holloway, R.L. (1979). Brain size allometry and reorganization. Toward a synthesis. In: Hahn, M.E., Jensen, C. and Dudek, B.C. (eds), Development and Evolution of Brain Size: Behavioral Implications. pp. 59-88. Academic Press, New York.

Holloway, R.L. (1982). Homo erectus brain endocasts: volumetric and morphological observations with some comments on cerebral asymmetries. In: Prétirage $I^{\circ}$ Congrès International de Paléontologie Humaine, Nice, pp. 355-369. CNRS.

Jacobson A.G. (1978). Some forces that shape the nervous system. Proceedings of the Symposium "Formshaping Movements in Neurogenesis", Uppsala September 1977, Zoon, 6, 13-21.

Kernan, J.D. (1916). The chondrocranium of a $20 \mathrm{~mm}$ human embryo. Journal of Morphology, 27.

Langman, J. (1984), Embryologie Médicale. Masson, Paris, 411 pp.

Leigh, S.R. (1992) Cranial Capacity Evolution in Homo erectus and Early Homo sapiens. American Journal of Physical Anthropology, 87, 1-13.

Lewis, W.H. (1920). The cartilaginous skull of human embryo $21 \mathrm{~mm}$ in length. Contributions from the Carnegie Institute, 9, 299-324.

Low, A. (1910). Further observations on the ossification of the human lower jaw. Journal of Anatomy and Physiology, 44, 83-93.

McHenry, H. (1991). First step? Analyses of the postcranium of early hominids. In: Origine(s) de la Bipédie chez les Hominidés, pp. 133-141. Cahiers de Paléoanthropologie, CNRS, Paris.

Masters, A.V., Falk, D. and Gage, T.B. (1991). Effects of age and gender on the location and orientation of the foramen magnum in Rhesus Macaques (Macaca mulatta). American Journal of Physical Anthropology, 86, 75-80.

Maureille, B. (1992). Immature Néandertalien, Implications sur la croissance faciale. Journal of the Israel Prehistory Society, Program and Book of Abstracts, pp. 79

Michejda, M. and Lamey D. (1971). Flexion and metric age changes of the cranial bases in Macaca mulatta. 1. Infants and juveniles. Folia Primatologica, 14, 84-94.

Müller, F. and O'Rahilly, R. (1980). The human chondrocranium at the end of the embryonic period proper, with particular reference to the nervous system. American Journal of Anatomy, 159, 33-58.

Müller, F. and O'Rahilly, R. (1980b). The early development of the nervous system in staged insectivore and primate embryos. Journal of Comparative Neurology, 193, 741-751.

Pope, G.G. (1992). Craniofacial evidence for the origin of modern humans in China. Yearbook of Physical Anthropology, 35, 243-298.

Rak, Y. (1985). Australopithecine Taxonomy and Phylogeny in Light of Facial Morphology. American Journal of Physical Anthropology, 66, 281-287. 
Rak, Y. and Howell F.C. (1978). Cranium of a juvenile Australopithecus boisei from the Lower Omo Basin, Ethiopia. American Journal of Physical Anthropology, 48, 345-366.

Roth, H. (1983). Comparaison statistique de la forme des arcades alvéolaire et dentaire des mandibules des hominidés fossiles. Museum National d'Histoire Naturelle, Laboratoire de paléontologie humaine et de préhistoire, Mémoire, 17, 2 vols, 477 pp.

Saban, R. (1977a). Le tracé des veines méningées moyennes chez I'Australopithèque. In: Fondation Singer Polignac (ed.), Les Origines et les Époques de l'Intelligence, pp. 107-116. Masson, Paris.

Saban, R. (1977b). Le réseau des veines méningées moyennes chez les Ponginés. Comptes Rendus de l'Académie des Sciences, Paris, série D, 28, 527-529.

Saban, R. (1980). Le système des veines méningées moyennes chez Homo erectus d'après le moulage endocrânien. Comptes Rendus des Sociétés Savantes, Science, 3, 99-120.

Saban, R. (1984). Anatomie et évolution des veines méningées chez les hommes fossiles. Mémoire de la Section des Sciences 11, C.T.H.S , Paris.

Saban, R. (1988). Le réseau méningé dans les crânes déformés: déformation toulousaine et déformation péruvienne Bulletin de la Société des Etudes et Recherche sur la Préhistoire des Eyzies, 37, 99-120.

Saban, R. (1990). Image of human fossil brain: endocranial casts and meningeal vessels in young and adult subject. Colloque International Fondation Fyssen, December 14-17 1990, Oxford University Press.

Schultz, A.H. (1926). Fetal growth of man and other primates. Quarterly Review of Biology, 1, 465-521.
Senut, B. (1982). Réflexions sur la brachiation et l'origine des Hominidés à la lumière des Hominoides miocènes et des Hominidés plio-pléistocènes. Geobios, mémoire spéciale 6, 335-344.

Senut, B. (1991). Origine(s) de la bipédie humaine: approche paléontologique. In: Origine(s) de la Bipédie chez les Hominidés. pp. 245-257, Cahiers de Paléoanthropologie, CNRS, Paris.

Stringer, C. (1990). The emergences of modern human. Scientific American, 263(6), 98-104.

Tardieu, C. (1991). Etude comparative des déplacements du centre de gravité du corps pendant la marche. In: Origine(s) de la Bipédie chez les Hominidés, pp. 49-58, Cahiers de Paléoanthropologie, CNRS, Paris.

Tobias, P.V. (1967). The cranium and maxillary dentition of Australopithecus (Zinjanthropus) boisei. In: Leakey, L.S.B. (ed.), Olduvai Gorge, Vol. 2, University Press, Cambridge.

Tobias, P. (1971). The brain in hominid evolution. 38th James Arthur Lecture, pp. 1-170. Columbia University Press, New York.

Tobias, P.V. (1983). Recent advances in the evolution of the hominids with especial reference to brain and speech. Scripta varia, Pontificia academia scientarum, 50, 85-139.

Tobias P.V. (1987) The brain of Homo habilis. A new level of organization in cerebral evolution. Journal of Human Evolution, 16, 741-761.

White, T. D. and Johanson, D. C. (1982). Pliocene hominid mandibles from Hadar, Ethiopia, 1974-1977 collections. American Journal of Physical Anthropology, 57, 501-544.

Wood, B. (1991). Koobi Fora Research Project, Vol.4. Hominid Cranial Remains. Clarendon Press, Oxford, 466 pp. 